\section{(A) Check for updates}

Cite this: Dalton Trans., 2017, 46 , 10090

Received 31st May 2017

Accepted 9th July 2017

DOI: $10.1039 / \mathrm{c} 7 \mathrm{dt} 01960 \mathrm{~b}$

rsc.li/dalton

\title{
Metal-mediated reactions between dialkylcyanamides and acetamidoxime generate unusual (nitrosoguanidinate)nickel(II) complexes $\uparrow$
}

\author{
Zarina M. Bikbaeva, Alexander S. Novikov, (D) Vitalii V. Suslonov, (D) \\ Nadezhda A. Bokach (D)* and Vadim Yu. Kukushkin (D)*
}

The nitrosoguanidinate complexes $\left[\mathrm{Ni}\left\{\mathrm{NH}=\mathrm{C}\left(\mathrm{NR} \mathrm{R}_{2}\right) \mathrm{NN}(\mathrm{O})\right\}_{2}\right]\left(\mathrm{R}_{2}=\mathrm{Me}_{2}\right.$ 1, $\left(\mathrm{CH}_{2}\right)_{4} \mathrm{O}$ 2, $\left(\mathrm{CH}_{2}\right)_{4}$ 3, $\left(\mathrm{CH}_{2}\right)_{5}$ 4, (Me)Ph 5, $\mathrm{Ph}_{2}$ 6, $\left(p-\mathrm{MeC}_{6} \mathrm{H}_{4}\right)_{2}$ 7) were obtained in low-to-moderate (12-26\%) yields but reproducible yields in an unexpected metal-mediated reaction in $\mathrm{MeOH}$ between the nickel salt $\mathrm{NiCl}_{2} \cdot 2 \mathrm{H}_{2} \mathrm{O}, \mathrm{N}, \mathrm{N}$ disubstituted cyanamides $\mathrm{NCNR}_{2}$, and the amidoxime $\mathrm{MeC}(=\mathrm{NOH}) \mathrm{NH}_{2}$. These complexes were formed along with a spectrum of cyanamide-oxime coupling products. The IR and X-ray data indicate the delocalization within the NNO and NCN systems of the nitrosoguanidinate ligand. This delocalization was additionally confirmed by inspection of Wiberg bond indices for the selected bonds. In the X-ray structure of $\mathbf{5}$, the rare metallophilic contacts $\mathrm{Ni}$...Ni between stacks of the square-planar complexes were detected and these non-covalent interactions were studied by non-relativistic and relativistic DFT calculations and topological analysis of the electron density distribution within the framework of Bader's theory (QTAIM method). The estimated strength of the $\mathrm{Ni} \cdots \mathrm{Ni}$ interactions is $1.3-1.9 \mathrm{kcal} \mathrm{mol}^{-1}$ and they are mostly determined by crystal packing effects and weak attractive interactions between adjacent metal centers due to the overlapping of their $\mathrm{d}_{z^{2}}$ and $\mathrm{p}_{z}$ orbitals.
\end{abstract}

\section{Introduction}

The reactions of metal-activated conventional nitriles NCR $(\mathrm{R}=$ alkyl and/or aryl) and such unconventional nitrile species as cyanamides $\mathrm{NCNR}_{2}$ have been intensively studied during the last two decades and impressive examples of differences in reactivity between these two types of nitriles are available in the literature (see, for instance, our review ${ }^{1}$ ). Thus, the guanidine $\{\mathrm{PhN}(\mathrm{H})\}_{2} \mathrm{C}=\mathrm{NH}$ reacts with dialkylcyanamide species bearing the cis-( $\left.\mathrm{NCNR}_{2}\right)_{2} \mathrm{Pt}^{\mathrm{II}}$ functionality to form eightmembered metallacycles stabilized due to an extended chain of conjugation (Scheme 1), whereas conventional nitrile complexes cis-(NCR) ${ }_{2} \mathrm{Pt}^{\mathrm{II}}$ form 1,3,5-triazapentadienate derivatives $\{\underline{N H}=\mathrm{C}(\mathrm{R}) \mathrm{NC}(\mathrm{R})=\underline{\mathrm{NH}}\} \mathrm{Pt}^{\mathrm{II}}$ (Scheme 1, a). ${ }^{2}$ Dialkylcyanamide ligands in cis-( $\left.\mathrm{NCNR}_{2}\right)_{2} \mathrm{Pt}^{\mathrm{IV}}$-type complexes undergo hydration coupling to form six-membered metallacycles, ${ }^{3}$ while conventional nitrile ligands form metal-bound carboxamides in their iminol form (b). ${ }^{4}$ Amidrazone derivatives were isolated in the

Saint Petersburg State University, 7/9 Universitetskaya Nab., 199034 Saint Petersburg, Russian Federation. E-mail: n.bokach@spbu.ru, v.kukushkin@spbu.ru

$\dagger$ Electronic supplementary information (ESI) available. CCDC 1530060 and 1530062-1530064. For ESI and crystallographic data in CIF or other electronic format see DOI: $10.1039 / \mathrm{c} 7 \mathrm{dt} 01960 \mathrm{~b}$ reaction of amidoximes with trans-( $\left(\mathrm{NCNR}_{2}\right)_{2} \mathrm{Pt}^{\mathrm{IV}}(\mathrm{c}){ }^{5}$ However, when complexes with the trans- $(\mathrm{NCR})_{2} \mathrm{Pt}^{\mathrm{IV}}$ moiety were treated with amidoximes, the reaction resulted in a bis-coupling product. ${ }^{6}$ These qualitative differences in reactivity between dialkylcyanamide and conventional nitrile ligands were documented mainly for platinum(II and iv) complexes and only a few relevant examples were reported for nickel(II) species. ${ }^{7}$

The reactions of nickel(II)-activated conventional nitriles with oximes were studied previously and a cascade reaction leading to the 1,3,5-triazapentadienate systems $\{\underline{\mathrm{NH}}=\mathrm{C}(\mathrm{R}) \mathrm{NC}$ $(\mathrm{R})=\mathrm{NH}\} \mathrm{Ni}^{\mathrm{II}}$ has been reported by Kopylovich and Pombeiro et al. $(\mathrm{d}){ }^{7,8}$ Recently, we reported on the reaction between $\mathrm{Ni}^{\mathrm{II}}$ bound dialkylcyanamides and oximes that leads to the generation of coordinated and uncomplexed coupling products featuring the $\left\{\mathrm{NH}=\mathrm{C}\left(\mathrm{NR}_{2}\right) \mathrm{ONCR}^{1} \mathrm{R}^{2}\right\} \mathrm{Ni}^{\mathrm{II}}$ and $\left[\mathrm{NH}=\mathrm{C}\left(\mathrm{NR}_{2}\right)\right.$ ONCR $\left.{ }^{1} \mathrm{R}^{2}\right]^{+}$moieties. The latter reaction differs from the reaction with conventional nitriles giving 1,3,5-triazapentadienate systems (d). ${ }^{8 a, e}$

In continuation of our studies of the reactivity of disubstituted cyanamides and conventional nitriles with different nucleophiles in the presence of nickel(II), ${ }^{8 a, 9}$ we turned our attention to amidoximes and observed an unusual transformation in the system $\mathrm{Ni}^{\mathrm{II}} / \mathrm{NCNR}_{2} / \mathrm{MeC}(=\mathrm{NOH}) \mathrm{NH}_{2}$ leading to the nitrosoguanidinate complexes $\left[\mathrm{Ni}\left\{\underline{\mathrm{NH}}=\mathrm{C}\left(\mathrm{NR}_{2}\right) \mathrm{NN}(\mathrm{O})\right\}_{2}\right]$. This transformation is realized only for cyanamides and not for 


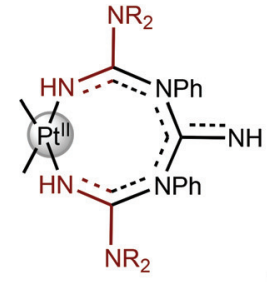

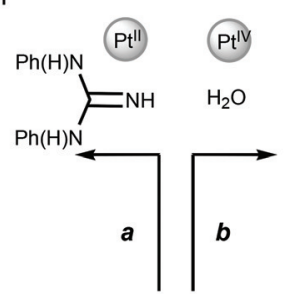

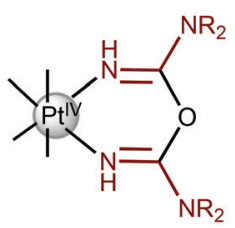<smiles>[R]C1=N[R17](C)(C)NC([R])=N1</smiles><smiles>[R]C(O)=NC(C)(C)C</smiles>
$\mathrm{NCNR}_{2}$ vs. NCR<smiles>[Y6]C1=N[R7](C)(C)N([R16])C([R])=N1</smiles><smiles></smiles>

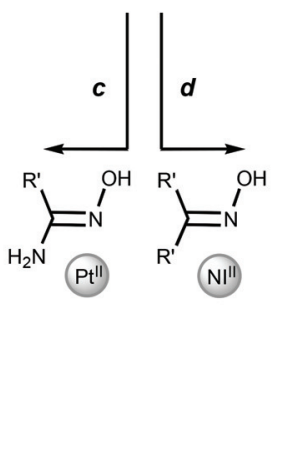

Scheme 1 Comparison of the metal-mediated conversions of cyanamide and nitrile ligands, emphasizing different reaction routes for these two types of nitrile species.

conventional nitriles and for acetamidoxime and not for other oximes. We report herein on the reaction of acetamidoxime with cyanamides in the presence of nickel salts that leads to a novel family of nitrosoguanidinate complexes, whose chemistry is still almost unexplored because of the harmful and explosive properties of uncomplexed nitrosoguanidines.

\section{Results and discussion}

For the study of the $\mathrm{Ni}^{\mathrm{II}}$-involving reactions between cyanamides and amidoximes we addressed the nickel salts $\mathrm{NiX}_{2} \cdot n \mathrm{H}_{2} \mathrm{O}$ (X = OTf, $n=0 ; \mathrm{Cl}, n=0,2$ or $6 ; \mathrm{Br}, n=3 ; \mathrm{I}, n=6$; $\left.\mathrm{NO}_{3}, n=6\right), N, N$-disubstituted cyanamides $\mathrm{NCNR}_{2}\left(\mathrm{R}_{2}=\mathrm{Me}_{2}\right.$, $\left.\left(\mathrm{CH}_{2}\right)_{4} \mathrm{O},\left(\mathrm{CH}_{2}\right)_{4},\left(\mathrm{CH}_{2}\right)_{5},(\mathrm{Me}) \mathrm{Ph}, \mathrm{Ph}_{2},\left(p-\mathrm{MeC}_{6} \mathrm{H}_{4}\right)_{2}\right)$, and acetamidoxime $\mathrm{MeC}(=\mathrm{NOH}) \mathrm{NH}_{2}$. These reactions were studied in methanol in which the nickel salts are rather well soluble. In the system $\mathrm{NiX}_{2} \cdot n \mathrm{H}_{2} \mathrm{O} / \mathrm{NCNR}_{2} / \mathrm{MeC}(=\mathrm{NOH}) \mathrm{NH}_{2}$, unexpected (nitrosoguanidinate) $\mathrm{Ni}^{\mathrm{II}}$ complexes 1-7 (Scheme 2) were reproducibly obtained in low-to-moderate $(12-26 \%)$ yields. The previously reported addition products featuring the $\left\{\underline{\mathrm{NH}}=\mathrm{C}\left(\mathrm{NR}_{2}\right)\right.$ $\left.\mathrm{ON}=\mathrm{C}\left(\mathrm{NH}_{2}\right) \mathrm{Me}\right\} \mathrm{Ni}^{\mathrm{II}}$ moiety, which were also formed in the

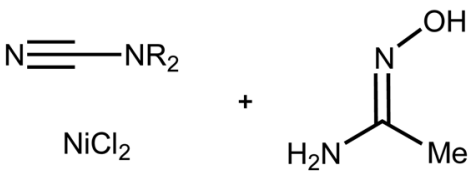

$\mathrm{MeOH}, 50^{\circ} \mathrm{C}$<smiles></smiles>

oily residues

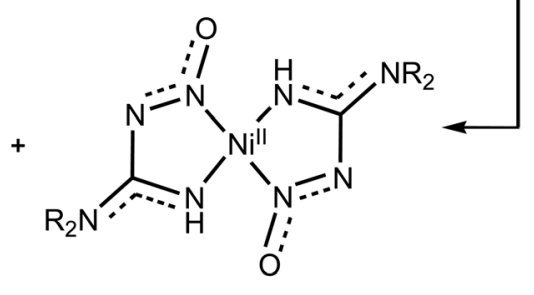

$1-7(12-26 \%)$
Scheme $2 \mathrm{Ni}$ "-Mediated generation of nitrosoguanidinate species 1-7 $\left(\mathrm{R}_{2}=\mathrm{Me}_{2} 1,\left(\mathrm{CH}_{2}\right)_{4} \mathrm{O} 2,\left(\mathrm{CH}_{2}\right)_{5} 3,\left(\mathrm{CH}_{2}\right)_{4} 4, \mathrm{Me} / \mathrm{Ph} 5, \mathrm{Ph}_{2} 6,\left(p-\mathrm{MeC}_{6} \mathrm{H}_{4}\right)_{2} 7\right)$.

reaction and released as oily residues, were identified by HRESI $^{+}$-MS and IR spectroscopy.

In the synthetic experiments, treatment of $\mathrm{NCNR}_{2}$ with the amidoxime $\mathrm{MeC}(=\mathrm{NOH}) \mathrm{NH}_{2}$ in the presence of $\mathrm{NiX}_{2} \cdot n \mathrm{H}_{2} \mathrm{O}$ in methanol at $50{ }^{\circ} \mathrm{C}$, followed by evaporation of the reaction mixture in air at RT $\left(20-25^{\circ} \mathrm{C}\right)$, results in the generation of 1-7 along with oily residues of other Ni-containing products. Among the tested nickel salts, the highest yields of the nitrosoguanidinate complexes were achieved for $\mathrm{NiCl}_{2} \cdot 2 \mathrm{H}_{2} \mathrm{O}$. The usage of the highly hydrated salt $\mathrm{NiCl}_{2} \cdot 6 \mathrm{H}_{2} \mathrm{O}$ or the addition of one drop of $\mathrm{H}_{2} \mathrm{O}$ to the reaction mixtures leads to similar yields to those obtained in the reaction with $\mathrm{NiCl}_{2} \cdot 2 \mathrm{H}_{2} \mathrm{O}$, whereas the usage of non-hydrated $\mathrm{NiCl}_{2}$ leads to slightly lower yields. We optimized the reaction conditions by varying the ratio between the components of the system $\mathrm{NiCl}_{2} \cdot 2 \mathrm{H}_{2} \mathrm{O} /$ $\mathrm{NCNMe}_{2} / \mathrm{MeC}(=\mathrm{NOH}) \mathrm{NH}_{2}($ molar ratios $1 / 2.5 / 2.5,1 / 2.5 / 5,1 / 5 /$ 2.5 , and $1 / 10 / 2.5$ were used) and also temperature (RT, $50{ }^{\circ} \mathrm{C}$, and $70{ }^{\circ} \mathrm{C}$ ). The optimal condition is a system with a $1 / 2.5 / 2.5$ ratio among the reactants and a temperature of $50{ }^{\circ} \mathrm{C}$ that gave 1 in $15 \%$ yield. The solvent choice is important; thus, 1-7 were not formed in acetone, while the application of undried ethanol in the system $\mathrm{NiCl}_{2} \cdot 2 \mathrm{H}_{2} \mathrm{O} / \mathrm{NCNMe}_{2} / \mathrm{MeC}(=\mathrm{NOH}) \mathrm{NH}_{2}$ also led to 1 and this compound was isolated in $12 \%$ yield.

The positive-mode HRESI-MS spectra of the oily residues obtained from $\mathrm{NiCl}_{2} \cdot 2 \mathrm{H}_{2} \mathrm{O} / \mathrm{NCNR}_{2} / \mathrm{MeC}(=\mathrm{NOH}) \mathrm{NH}_{2}$ systems exhibit several groups of peaks with characteristic isotopic patterns corresponding to the $\left[\mathrm{H}_{2} \mathrm{~N}=\mathrm{C}\left(\mathrm{NR}_{2}\right) \mathrm{ON}=\mathrm{C}\left(\mathrm{Me}^{2} \mathrm{NH}_{2}\right]^{+}\right.$, $\left[\mathrm{Ni}\left\{\mathrm{NH}=\mathrm{C}\left(\mathrm{NR}_{2}\right) \mathrm{ONC}(\mathrm{Me}) \mathrm{NH}_{2}\right\}_{2}\right]^{2+},\left[\mathrm{NiCl}\left\{\mathrm{NH}=\mathrm{C}\left(\mathrm{NR}_{2}\right) \mathrm{ONC}(\mathrm{Me})\right.\right.$ $\left.\left.\mathrm{NH}_{2}\right\}\right]^{+}$, and $\left[\mathrm{NiCl}\left\{\mathrm{NH}=\mathrm{C}\left(\mathrm{NR}_{2}\right) \mathrm{ONC}(\mathrm{Me}) \mathrm{NH}_{2}\right\}_{2}\right]^{+}\left(\mathrm{R}=\mathrm{Me}_{2}\right.$, $\left.\left(\mathrm{CH}_{2}\right)_{4} \mathrm{O},\left(\mathrm{CH}_{2}\right)_{4},\left(\mathrm{CH}_{2}\right)_{5}, \mathrm{Ph}_{2},(\mathrm{Me}) \mathrm{Ph}\right)$ ions, which reflect the formation of the coupling product. It is noteworthy that these signals appeared in the HRESI ${ }^{+}$-MS spectra already after $2 \mathrm{~h}$ of reaction. The IR spectra of the reaction mixture $\mathrm{NiCl}_{2} \cdot 2 \mathrm{H}_{2} \mathrm{O} /$ $\mathrm{NCNMe}_{2} / \mathrm{MeC}(=\mathrm{NOH}) \mathrm{NH}_{2}$ were measured at different time intervals $(0 \mathrm{~h}, 2 \mathrm{~h}$, and $4 \mathrm{~h})$. In the first and the second spectra, an absorption band from $\nu(\mathrm{C} \equiv \mathrm{N})$ at $2216-2264 \mathrm{~cm}^{-1}$ 
was observed. In the IR spectra recorded after $4 \mathrm{~h}$, this band was not found, whereas several new intensive bands from $\nu(\mathrm{C}=\mathrm{N})$ in the range of $1635-1675 \mathrm{~cm}^{-1}$ were observed instead that indicates total conversion of $\mathrm{NCNR}_{2}$ into coordinated $\mathrm{NH}=\mathrm{C}\left(\mathrm{NR}_{2}\right) \mathrm{ONC}\left(\mathrm{NH}_{2}\right) \mathrm{Me}$. These observations give evidence of $\mathrm{Ni}^{\mathrm{II}}$-mediated amidoxime-cyanamide coupling leading to nickel(II) complexes featuring the $\left\{\underline{\mathrm{NH}}=\mathrm{C}\left(\mathrm{NR}_{2}\right) \mathrm{ONC}\left(\mathrm{NH}_{2}\right) \mathrm{Me}\right\}$ $\mathrm{Ni}^{\mathrm{II}}$ functionality. These observations are in agreement with the previously reported $\mathrm{Ni}^{\mathrm{II}}$-mediated oxime-cyanamide coupling leading to nickel(II) complexes $\left\{\underline{N H}=\mathrm{C}\left(\mathrm{NR}_{2}\right) \mathrm{ONC}\left(\mathrm{R}^{\prime}\right) \mathrm{Me}\right\}$ $\mathrm{Ni}^{\mathrm{II}}\left(\mathrm{R}^{\prime}=\mathrm{Me}, \mathrm{Ph}\right)^{8 a}$ and also $\mathrm{Zn}^{\mathrm{II}-10}$ and $\mathrm{Pt}^{\mathrm{II}}{ }^{- \text {mediated }^{11}}$ amidoxime-cyanamide coupling leading to complexes with $\underline{\mathrm{NH}}=\mathrm{C}$ $\left(\mathrm{NR}_{2}\right) \mathrm{ONC}\left(\mathrm{NH}_{2}\right) \mathrm{R}^{\prime}$ ligands. The coupling products were not isolated in pure forms, probably due to high kinetic lability of nickel(II) complexes and the existence of nickel(II) products with coordinated carbimidoylamidoxime in several forms. ${ }^{8 a}$

We also conducted a metal-free blank experiment and found that keeping a mixture of $\mathrm{NCNMe}_{2}$ and $\mathrm{MeC}(=\mathrm{NOH})$ $\mathrm{NH}_{2}$ in a 1:1 molar ratio in the absence of any nickel(II) salt under the conditions of the nickel(II)-mediated reaction does not give the coupling products or uncomplexed nitrosoguanidine species even after $5 \mathrm{~d}$. Therefore, one can conclude that the formation of nitrosoguanidine species is metal-mediated.

Other compounds that behave as simultaneous nucleophiles and "NO" sources, such as $\mathrm{HONH}_{2}{ }^{12}$ and $\mathrm{HON}=\mathrm{CMe}_{2},{ }^{13}$ were tested in the $\mathrm{Ni}^{\mathrm{II}}$-involving reaction with $\mathrm{NCNMe}_{2}$. However, no nitrosoguanidinate species were obtained and/or identified in the reaction mixture. The known 1,3,5-triazapentadienate complex $[\mathrm{Ni}\{\mathrm{HN}=\mathrm{C}(\mathrm{OMe}) \mathrm{NC}(\mathrm{OMe})=$ $\left.\underline{\mathrm{NH}}\}_{2}\right]^{14}$ was isolated from the system $\mathrm{NiCl}_{2} \cdot 2 \mathrm{H}_{2} \mathrm{O} / \mathrm{NCNMe}_{2} /$ $\mathrm{HON}=\mathrm{CMe}_{2}$ in $5 \%$ yield. The application of the other amidoximes $\mathrm{R}^{\prime} \mathrm{C}(=\mathrm{NOH}) \mathrm{NH}_{2}\left(\mathrm{R}^{\prime}=\mathrm{PhCH}_{2}, \mathrm{Ph}, p-\mathrm{BrC}_{6} \mathrm{H}_{4}\right)$ in the reaction does not lead to 1-7. We assume that this difference in reactivity could be explained by the greater nucleophilicity of $\mathrm{HON}=\mathrm{C}\left(\mathrm{NH}_{2}\right) \mathrm{Me}$ than that of the other tested amidoximes. The application of conventional nitriles NCR $(\mathrm{R}=\mathrm{Me}, \mathrm{Ph})$ in the reaction with $\mathrm{NiCl}_{2} \cdot 2 \mathrm{H}_{2} \mathrm{O} / \mathrm{HON}=\mathrm{C}\left(\mathrm{NH}_{2}\right) \mathrm{Me}$ in $\mathrm{MeOH}$ does not lead to similar nitrosoamidine complexes. The difference between cyanamides and conventional nitriles in reactivity is mostly due to the presence, in cyanamides, of the $\mathrm{NR}_{2}$ group exhibiting strong $+\mathrm{M}$ effect.

Based on our observations and the literature data, we assume that the formation of 1-7 is a result of a few consecutive $\mathrm{Ni}^{\mathrm{II}}$-mediated reactions. Initially, the acetamidoxime reacts with $\mathrm{Ni}^{\mathrm{II}}$-activated cyanamide to form coupling products featuring the $\left\{\underline{N H}=\mathrm{C}\left(\mathrm{NR}_{2}\right) \mathrm{ON}=\mathrm{C}\left(\mathrm{NH}_{2}\right) \mathrm{Me}\right\} \mathrm{Ni}^{\mathrm{II}}$ chelated ring (Scheme 3). The generation of stable isostructural coupling products was previously observed for the relevant system $\mathrm{Ni}^{\mathrm{II}}$ / $\mathrm{NCNR}_{2} /$ ketoxime. $^{8 a}$ Probably, the other amidoximes are not active in the generation of (nitrosoguanidinate) $\mathrm{Ni}^{\mathrm{II}}$ species due to their lower nucleophilicity. ${ }^{15}$

These coupling products could further react with wet $\mathrm{MeOH}$ to give $\mathrm{O}=\mathrm{C}\left(\mathrm{NR}_{2}\right) \mathrm{NH}_{2}, \mathrm{HNR}_{2}, \mathrm{NH}_{3}, \mathrm{CO}_{2}$, and the parent amidoxime $\mathrm{MeC}(=\mathrm{NOH}) \mathrm{NH}_{2}$ (c). Similar transformations were postulated for the $\mathrm{Ni}^{\mathrm{II}}$-mediated reaction of dialkylcyanamides with pyrazoles in undried $\mathrm{MeOH} .{ }^{9}$ Ammonia, which was

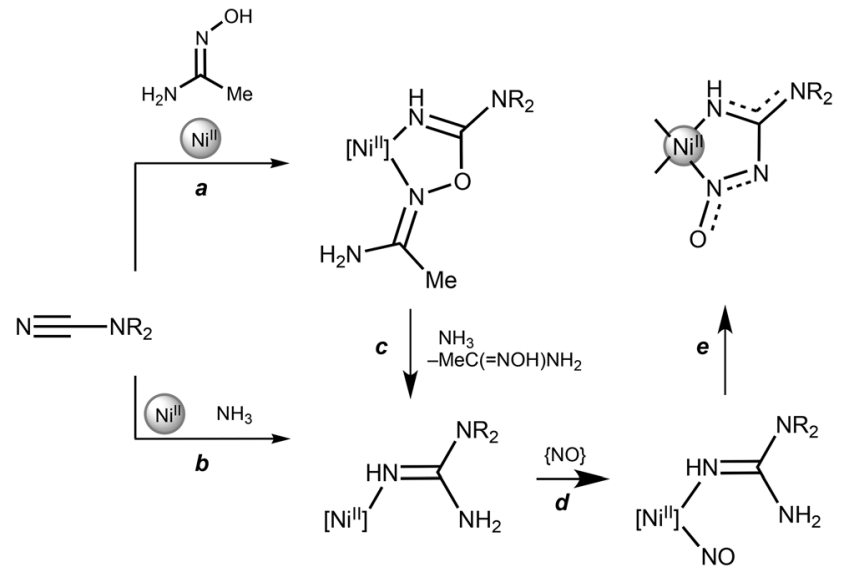

Scheme 3 A plausible mechanism for the generation of (nitrosoguanidinate) $\mathrm{Ni}^{\mathrm{Il}}$ complexes.

accumulated in the reaction mixture, reacted with either the $\left(\mathrm{NCNR}_{2}\right) \mathrm{Ni}^{\mathrm{II}}$ (b) or $\left\{\mathrm{HN}=\mathrm{C}\left(\mathrm{NR}_{2}\right) \mathrm{ON}=\mathrm{C}\left(\mathrm{NH}_{2}\right) \mathrm{Me}\right\} \mathrm{Ni}^{\mathrm{II}}$ (c) species, producing complexes featuring the $\left\{\mathrm{HN}=\mathrm{C}\left(\mathrm{NR}_{2}\right)\right.$ $\left.\mathrm{NH}_{2}\right\} \mathrm{Ni}^{\mathrm{II}}$ functionality via nucleophilic addition (b) or Pinnerlike nucleophilic substitution (c) routes. Addition of external ammonia to the $\mathrm{NiCl}_{2} \cdot 2 \mathrm{H}_{2} \mathrm{O} / \mathrm{NCNMe}_{2} / \mathrm{MeC}(=\mathrm{NOH}) \mathrm{NH}_{2}$ system in methanol does not change the yield of the reaction.

Ammonia is likely generated in situ from $\mathrm{NCNR}_{2}$ (or its coupling products) via nickel(II)-mediated hydrolysis, whereupon $\mathrm{NH}_{3}$ adds to another nitrile group to give a guanidine moiety (c). Previously, one of us reported the relevant $\left(\mathrm{Co}^{\mathrm{II}} /\right.$ oxime)-mediated conversion of nitriles $\mathrm{NCR}(\mathrm{R}=$ alkyl, aryl) leading to amidines $\mathrm{RC}\left(\mathrm{NH}_{2}\right)=\mathrm{NH} .{ }^{16}$ In the latter transformation, again, the addition of external ammonia does not affect the yield of the formed amidines. Furthermore, the generation of coupling products with in situ generated ammonia was observed upon metal-mediated syntheses of 1,3,5-triazapentadienes (for a review on triazapentadiene complexes see ref. $8 b$ ), phthalocyanines, ${ }^{8 c, 17}$ diacylamides, ${ }^{18} \mathrm{~N}$-acylamidines, ${ }^{19}$ imidic anhydrides, ${ }^{3}$ and amidines. ${ }^{16,20}$ Our current experiments and the previous data ${ }^{8 a, 17-20}$ suggest that the mechanism of the reaction shown in Scheme 3 is not simple and perhaps involves internal generation of ammonia at a nickel(II) center as one of the fast reaction steps.

Independently, $\mathrm{MeC}(=\mathrm{NOH}) \mathrm{NH}_{2}$ could be subjected to oxidative hydrolysis to give an "NO" source. The relevant $\mathrm{Ni}^{\mathrm{II}}$ mediated nitrosation with hydroxylamine formed in situ upon ketoxime hydrolysis is known. ${ }^{21}$ Once NO is formed, it coordinates to the $\mathrm{Ni}^{\mathrm{II}}$ center (d) and then couples with the guanidine ligand producing the $\left\{\underline{N} \mathrm{H}=\mathrm{C}\left(\mathrm{NR}_{2}\right) \mathrm{N} \underline{\mathrm{N}}(\mathrm{O})\right\} \mathrm{Ni}^{\mathrm{II}}$ group (e). Step e of the nitrosyl-guanidine coupling is analogous to that observed in the reaction between the amidinate complex $\left[\mathrm{Fe}\{\mathrm{RNC}(\mathrm{Me}) \mathrm{NR}\}_{3}\right]\left(\mathrm{R}=p-\mathrm{MeC}_{6} \mathrm{H}_{4}\right)$ and NO. ${ }^{22}$ This reaction leads to $\left[\mathrm{Fe}\{\mathrm{N}(\mathrm{O}) \mathrm{N}(\mathrm{R}) \mathrm{C}(\mathrm{Me}) \mathrm{NR}\}\left\{\mathrm{RNC}(\mathrm{Me}) \mathrm{NR}_{2}\right]\right.$ and the complex is formed through intramolecular nitrosyl-amidinate coupling at the iron center. It is noteworthy that formally reverse reaction -i.e. when the $\mathrm{NHC}-\mathrm{N}_{2} \mathrm{O}$ adducts $(\mathrm{NCH}=1,3$-dimesitylimidazol-2-ylidene and 1,3-diisopropylimidazol-2-ylidene) featuring 
the same $\mathrm{N}_{2} \mathrm{CNN}=\mathrm{O}$ linkage react with the $\mathrm{Ni}(\mathrm{COD})_{2}$ complex -includes the $\mathrm{N}-\mathrm{N}$ bond cleavage leading to the nitrosyl nickel complex and guanidinate ligands. ${ }^{23}$

We added gaseous $\mathrm{NO}$ to the reaction mixture $\mathrm{NiCl}_{2} \cdot 2 \mathrm{H}_{2} \mathrm{O}$ / $\mathrm{NCNMe}_{2} / \mathrm{MeC}(=\mathrm{NOH}) \mathrm{NH}_{2}\left(\mathrm{MeOH}, 50{ }^{\circ} \mathrm{C}, 1 \mathrm{~d}\right)$ and kept it for several days for slow evaporation. We observed the formation of 1 , but its yield was exactly the same (15\%) as in the experiment without the addition of NO. These observations also support the idea that NO is formed in situ as one of the fast reaction steps.

In the context of the generation of nitrosoguanidine nickel(II) species, it is noteworthy that uncomplexed nitrosoguanidines are known and they are typically synthesized by reduction of the corresponding nitroguanidines with $\mathrm{Zn}$ dust or RANEY® nickel $/ \mathrm{H}_{2}{ }^{24}$ other methods for the preparation of the nitrosoguanidines are still undeveloped. Nitrosoguanidine itself is an explosive crystalline material, ${ }^{25} \mathrm{~N}$-alkylated nitrosoguanidines were studied as intermediates of the biosynthetic conversion of L-arginine to nitric oxide, ${ }^{26}$ whereas another nitrosoguanidine derivative, viz. $N$-methyl- $N$ '-nitro- $N$-nitrosoguanidine, is widely applied for directed mutagenesis in the selection of plants and microorganisms ${ }^{27}$ and it is also used in industry as an exciting explosive with a high thermal stability. ${ }^{28}$

\section{Characterization of 1-7}

Complexes 1-7 were characterized by $\mathrm{C}, \mathrm{H}$, and $\mathrm{N}$ elemental analyses, HRESI ${ }^{+}$-MS, FTIR, ${ }^{1} \mathrm{H}$ and ${ }^{13} \mathrm{C}\left\{{ }^{1} \mathrm{H}\right\}$ NMR, TG/DTA, and single-crystal X-ray diffraction (for $\mathbf{1}$ and 3-5). Nitrosoguanidinate complexes 1-7 are stable until $194-240{ }^{\circ} \mathrm{C}$ (Fig. S7, S13, S19, S25, S31, S37 and S43; ESI $\dagger$ ) and then gradually decompose at higher temperatures. All complexes gave satisfactory $\mathrm{C}, \mathrm{H}$, and $\mathrm{N}$ elemental analyses for the proposed formulas. The HRESI $^{+}$-MS spectra exhibit several groups of peaks with characteristic isotopic patterns corresponding to the $[\mathrm{M}+\mathrm{H}]^{+},[\mathrm{M}+\mathrm{Na}]^{+},[2 \mathrm{M}+\mathrm{Na}]^{+},[3 \mathrm{M}+\mathrm{Na}]^{+}([\mathrm{M}]=$ $\left.\left[\mathrm{Ni}\left\{\mathrm{NH}=\mathrm{C}\left(\mathrm{NR}_{2}\right) \mathrm{NN}(\mathrm{O})\right\}_{2}\right]\right)$ ions.

In the IR spectra of 1-7, absorption bands from $\nu(\mathrm{N}-\mathrm{H})$ (3352-3476 $\left.\mathrm{cm}^{-1}\right), \nu(\mathrm{C}=\mathrm{N})\left(1566-1608 \mathrm{~cm}^{-1}\right)$, and $\nu(\mathrm{N}=\mathrm{O})$ (1386-1414 $\mathrm{cm}^{-1}$ ) appeared at the expected ranges (Fig. S3, S9, S15, S21, S27, S33 and S39; ESI $\dagger$ ). ${ }^{29}$ It is noteworthy that $\nu(\mathrm{N}=\mathrm{O})$ of the nitroso group of the complexed nitrosoguanidinates exhibit substantially smaller values than those for the uncomplexed neutral $\mathrm{H}_{2} \mathrm{NC}(=\mathrm{NH}) \mathrm{NHNO}$ species $^{25}$ $\left(1520 \mathrm{~cm}^{-1}\right)$, thus demonstrating reduction of the multiplicity of the $\mathrm{N}=\mathrm{O}$ bond upon deprotonation and complexation. The $\nu(\mathrm{N}=\mathrm{O})$ absorption bands of 1-7 exhibit intermediate values between the values of double $\left(1500-1480 \mathrm{~cm}^{-1}\right.$ in nitrosamines $\mathrm{R}_{2} \mathrm{~N}-\mathrm{N}=\mathrm{O}^{29}$ ) and single (1310-1250 $\mathrm{cm}^{-1}$ in azoxy species $\mathrm{R}-\mathrm{N}=\mathrm{N} \rightarrow \mathrm{O}^{29}$ ) NO stretches, thus indicating intermediate bond order within the nitroso fragment. These data are consistent with X-ray structure parameters of $\mathbf{1}$ and 3-5 whose inspection suggests the delocalization. This delocalization was also supported by analysis of the calculated Wiberg bond indices for selected bonds (see later).

In the ${ }^{1} \mathrm{H}$ NMR spectra (Fig. S5, S11, S17, S23, S29, S35 and $\mathrm{S} 41$; $\mathrm{ESI}_{\dagger} \dagger$ ), the signals of the $=\mathrm{NH}$ protons appeared in the
3.56-3.75 ppm range for 1 and 4 and 4.33-4.65 ppm for 2, 3, and 5-7. In the ${ }^{13} \mathrm{C}\left\{{ }^{1} \mathrm{H}\right\} \mathrm{NMR}$, resonances of the methyl groups are at $21 \mathrm{ppm}$ for 7 and in the range 37-41 ppm for $\mathbf{1}$ and 5; $\mathrm{NCH}_{2}$ appear at 46-49 ppm for 2, 3, and 4; $\mathrm{CH}_{\mathrm{Ar}}$ emerge at 126-131 ppm, and $\mathrm{C}_{\text {ipso }}$ at 126-142 ppm for 5, 6, and 7. One signal in the interval 164.91-167.25 ppm refers to the quaternary carbon atom of the nitrosoguanidinate moiety $\mathrm{N}(\mathrm{H})=C$ (Fig. S6, S12, S18, S24, S30, S36 and S42; ESI $\dagger$ ).

Complexes 1-7 are red or purple colored. The absorption spectra of all complexes 1-7 display similar spectral patterns with several intensive absorption bands in the near-UV region. The most intense absorption bands are located in the 251-254 $(\lg \varepsilon$ 3.27-3.35) and 312-329 ( $\lg \varepsilon$ 3.02-3.47) nm ranges along with four bands of low intensity in the intervals 395-407 ( $\lg \varepsilon$ 2.26-2.63), 459-466 ( $\lg \varepsilon$ 1.95-2.09), 526-538 ( $\lg \varepsilon$ 2.01-2.20), and 558-570 ( $\lg \varepsilon$ 1.93-2.14) $\mathrm{nm}$ (in $\mathrm{CH}_{2} \mathrm{Cl}_{2}$; Fig. S4, S10, S16, S22, S28, S34 and S40; ESI $\dagger$ ). For theoretical discussions on the nature of the singlet excited electronic states of $\mathbf{1}$ and the assignment of the most significant transitions see the ESI. $\dagger$

\section{Solid-state structures of the nitrosoguanidinate complexes}

X-ray structure determination. Single-crystal X-ray diffraction studies were performed for five compounds, viz. 1 and 3-5 (Fig. 1 and Fig. S45-S48, Table S2; ESI†). The geometric characteristics of $\mathbf{1}$ and 3-5 agree with each other and also with the reported X-ray structure of $\left[\mathrm{Ni}\left\{\underline{\mathrm{NH}}=\mathrm{C}\left(\mathrm{NH}_{2}\right) \mathrm{N} \underline{N}(\mathrm{O})\right\}\right] .{ }^{30}$ In all structures, the nickel centers exhibit a planar environment (geometry index $\tau_{4}=0$ (ref. 31)).

The $\mathrm{N}(1)-\mathrm{N}(3)$ and $\mathrm{N}(1)-\mathrm{O}(1)$ bond lengths are 1.3006(16)$1.320(4) \AA$ and $1.240(3)-1.256(4) \AA$, respectively. These distances are coherent with those in the previously reported complex $\left[\mathrm{Ni}\left\{\underline{\mathrm{NH}}=\mathrm{C}\left(\mathrm{NH}_{2}\right) \mathrm{NN}(\mathrm{O})\right\}_{2}\right](\mathrm{N}(1)-\mathrm{N}(3)$ 1.285(9) $⿱$ $; \mathrm{N}(1)-$ $\mathrm{O}(1)$ 1.260(9) $\AA$ (ref. 30)). The distances N(1)-N(3) (1.3006(16)$1.320(4) \AA)$ exhibit values similar to the N-N distance in pyridazine $(1.304(19) \AA)^{32}$ favoring intermediate $\mathrm{N}(1) \mathrm{N}(3)$ bond order. The distances $\mathrm{N}(1)-\mathrm{O}(1)$ have intermediate values between single $\mathrm{N}_{\mathrm{sp}^{2}} \mathrm{O}\left(1.394(18) \AA\right.$ in oximes $\left.{ }^{32}\right)$ and double $\mathrm{N}=\mathrm{O}$ $\left(1.218(13) \AA\right.$ in the nitro group $\left.{ }^{32}\right)$ bonds. Thus, the $\mathrm{N}(1)-\mathrm{N}(3)$

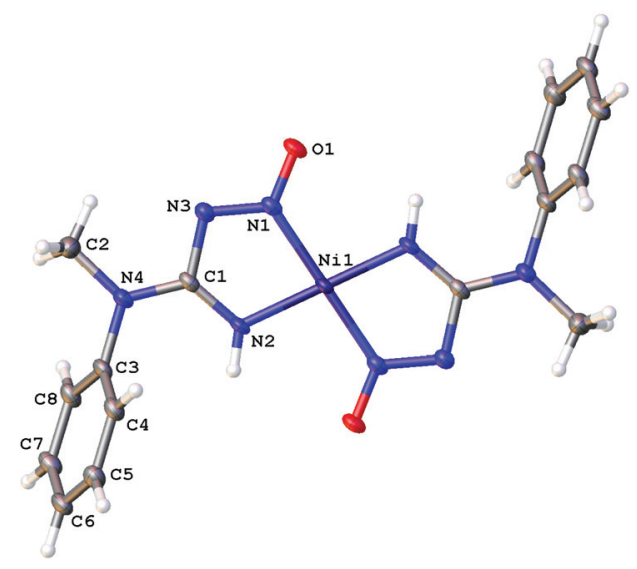

Fig. 1 Molecular structure of 5 with the atomic numbering scheme. ADP ellipsoids are drawn at the $50 \%$ probability level. 
and $\mathrm{N}(1)-\mathrm{O}(1)$ bonds have intermediate bond order, which is in agreement with the IR data for complexes 1-7 (see above). The $\mathrm{C}(1)-\mathrm{N}(3)$ bond length $(1.391(2)-1.411(5) \AA)$ is only slightly longer than the typical single $\mathrm{C}_{\mathrm{sp}^{2}}-\mathrm{N}(2)$ bond (e.g. 1.376(11) $\AA$ in imidazole ${ }^{32}$ ), thus reflecting its single bond character. These statements are consistent with the theoretically calculated bond orders (Tables 1 and 2).

All other bonds are of normal values (for a detailed discussion see the ESI $\dagger$ ). Inspection of the crystallographic data did not reveal the presence of any metallophilic contacts in crystal structures of $\mathbf{1}, \mathbf{3}$, and $\mathbf{4}$, but in $\mathbf{5}$ this type of non-covalent interaction was detected and confirmed theoretically (see the Computational studies section later).

Analysis of the Wiberg bond indices. This analysis for some selected bonds in the gas phase optimized structures of 1, 3, 4, and 5 , computed using the natural bond orbital (NBO) partitioning scheme at the M06/6-311+G* level of theory, reveals a noticeable degree of electron density delocalization in the chelated fragments of these species, viz., Wiberg bond indices are close to 1.5 for N2-C1 and N3-N1 contacts and noticeably deviate from 1.0 for $\mathrm{C} 1-\mathrm{N} 4$ and $\mathrm{C} 1-\mathrm{N} 3$ contacts (Table 1). These theoretical calculation data agree well with the experi-

Table 1 Calculated Wiberg bond indices for selected bonds in gas phase optimized structures of $1,3,4$, and 5 (M06/6-311+G* level of theory)

\begin{tabular}{lllll}
\hline Bond & $\mathbf{1}$ & $\mathbf{3}$ & $\mathbf{4}$ & $\mathbf{5}$ \\
\hline Ni1-N2 & 0.56 & 0.55 & 0.56 & 0.56 \\
N2-C1 & 1.44 & 1.45 & 1.44 & 1.45 \\
C1-N4 & 1.20 & 1.19 & 1.20 & 1.18 \\
C1-N3 & 1.15 & 1.15 & 1.15 & 1.16 \\
N3-N1 & 1.40 & 1.40 & 1.40 & 1.39 \\
N1-Ni1 & 0.55 & 0.55 & 0.55 & 0.55
\end{tabular}

mental (IR and X-ray diffraction) observations and the results of our previous DFT study on electron density delocalization in $\left[\mathrm{Ni}\left\{\mathrm{NH}=\mathrm{C}\left(\mathrm{NMe}_{2}\right) \mathrm{ON}=\mathrm{CMe}_{2}\right\}_{2}\left(\mathrm{H}_{2} \mathrm{O}\right)_{2}\right]^{2+}$ (ref. $8 a$ ) and $\left[\mathrm{H}_{2} \mathrm{~N}\right] \mathrm{C}$ (R)ON]C( $\left.\left.\mathrm{R}^{\prime}\right) \mathrm{NH}_{2}\right]^{+}$(ref. 33) species.

Computational studies. Inspection of the crystallographic data reveals the presence of metallophilic interactions $\mathrm{Ni} \cdot \cdots \mathrm{Ni}$ in the crystal structure of 5 obtained at $100 \mathrm{~K}$ (structure 5-100) and at room temperature (structure 5-RT). Indeed, in both cases the distance between appropriate metal centers is lower than the sum of their van der Waals (vdW) radii. One should take into consideration that such radii cannot be unambiguously defined and to date several values of vdW radii for nickel based on different approaches have been proposed, varying from 1.63 (ref. 34 ) to $2.40 \AA^{35}{ }^{35}$ Taking into consideration that metallophilic interactions often impart important properties to functional materials (viz., magnetism, conductivity, or luminescence ${ }^{36}$ ) and, in addition, that only one theoretical study was performed by us on the metallophilic nature of $\mathrm{Ni}^{\mathrm{II}} \cdot \mathrm{Ni}^{\mathrm{II}}$ short contacts and their energies were reported, ${ }^{9}$ in the current work a detailed computational study of this phenomenon has been performed.

In order to confirm or disprove the hypothesis on the existence of these non-covalent interactions and to quantify their energies from a theoretical viewpoint, we carried out non-relativistic and relativistic DFT calculations and topological analysis of the electron density distribution within the framework of Bader's theory (QTAIM method) ${ }^{37}$ for the oligomeric clusters 5-100 and 5-RT as model systems (Table 3 and Table S3†). This approach has already been successfully used by us in studies on the non-covalent interactions and properties of coordination bonds in various transition metal complexes. ${ }^{9,38}$ The contour line diagram of the Laplacian distribution $\nabla^{2} \rho(r)$, bond paths, and selected zero-flux surfaces for Ni $\cdots \mathrm{Ni}$ metallophilic interactions in $\mathbf{5 - 1 0 0}$ is shown in Fig. 2. To visualize the

Table 2 Geometric characteristics of the uncomplexed nitrosoguanidine $\mathrm{H}_{2} \mathrm{~N}(=\mathrm{NH}) \mathrm{NHNO},{ }^{25}\left[\mathrm{Ni}\left\{\underline{\mathrm{NH}}=\mathrm{C}\left(\mathrm{NH} \mathrm{H}_{2}\right) \mathrm{N} \underline{N}(\mathrm{O})\right\}_{2}\right],{ }^{30} 1^{\text {, and } 3-5}$

\begin{tabular}{|c|c|c|c|c|c|c|c|}
\hline Distance, $\AA$ & $\mathrm{H}_{2} \mathrm{~N}(=\mathrm{NH}) \mathrm{NHNO}^{25}$ & $\mathrm{R}=\mathrm{NH}_{2}{ }^{30}$ & $\mathrm{R}=\mathrm{NMe}_{2}(\mathbf{1})$ & $\mathrm{R}=\mathrm{N}\left(\mathrm{CH}_{2}\right)_{5}(3)$ & $\mathrm{R}=\mathrm{N}\left(\mathrm{CH}_{2}\right)_{4}(\mathbf{4})$ & $\mathrm{R}=\mathrm{N}\left(\mathrm{CH}_{3}\right) \mathrm{Ph}(5)$ & $\mathrm{R}=\mathrm{N}_{\mathrm{A}}\left(\mathrm{C}_{\mathrm{A}} \mathrm{H}_{3 \mathrm{~A}}\right) \mathrm{Ph}_{\mathrm{A}}(5)$ \\
\hline $\mathrm{Ni}(1)-\mathrm{N}(2)$ & $1.260(2)$ & $1.851(6)$ & $1.841(3)$ & $1.8473(11)$ & $1.846(2)$ & $1.844(2)$ & $1.841(3)$ \\
\hline $\mathrm{N}(1)-\mathrm{N}(3)$ & $1.391(2)$ & $1.285(9)$ & $1.311(4)$ & $1.3006(16)$ & $1.305(3)$ & $1.320(4)$ & $1.307(4)$ \\
\hline $\mathrm{N}(3)-\mathrm{C}(1)$ & $1.315(2)$ & $1.404(11)$ & 1.411(5) & $1.4087(17)$ & $1.408(3)$ & $1.407(4)$ & $1.404(4)$ \\
\hline $\mathrm{C}(1)-\mathrm{N}(2)$ & $1.309(2)$ & $1.297(11)$ & $1.318(4)$ & $1.3112(17)$ & $1.314(3)$ & $1.303(4)$ & $1.319(4)$ \\
\hline $\mathrm{C}(1)-\mathrm{N}(4)$ & & $1.321(11)$ & $1.332(4)$ & $1.3377(17)$ & $1.331(3)$ & $1.347(4)$ & $1.334(4)$ \\
\hline Angle, ${ }^{\circ}$ & $\left(\mathrm{NH}_{2}\right)_{2} \mathrm{CN}_{2} \mathrm{O}$ & $\mathrm{R}=\mathrm{NH}_{2}$ & $\mathrm{R}=\mathrm{NMe}_{2}$ & $\mathrm{R}=\mathrm{N}\left(\mathrm{CH}_{2}\right)_{5}$ & $\mathrm{R}=\mathrm{N}\left(\mathrm{CH}_{2}\right)_{4}$ & $\mathrm{R}=\mathrm{N}\left(\mathrm{CH}_{3}\right) \mathrm{Ph}$ & $\mathrm{R}=\mathrm{N}_{\mathrm{A}}\left(\mathrm{CAH}_{3 \mathrm{~A}}\right) \mathrm{Ph}_{\mathrm{A}}$ \\
\hline & $119.2(5)$ & $119.0(2)$ & 119.84(9) & 119.33(15) & 118.91(19) & 118.73(19) \\
\hline \multicolumn{2}{|c|}{$\begin{array}{l}\mathrm{Ni}(1)-\mathrm{N}(1)-\mathrm{N}(3) \\
\mathrm{Ni}(1)-\mathrm{N}(1)-\mathrm{O}(1)\end{array}$} & $124.0(5)$ & 123.3 & $123.46(9)$ & $122.89(16)$ & $124.4(2)$ & $123.6(2)$ \\
\hline \multicolumn{2}{|c|}{$\mathrm{N}(1)-\mathrm{Ni}(1)-\mathrm{N}(2)$} & $80.9(3)$ & $81.46(12)$ & $81.42(5)$ & $81.39(9)$ & $81.42(11)$ & $81.45(11)$ \\
\hline $\mathrm{Ni}(1)-\mathrm{N}(2)-\mathrm{C}($ & $115.0(2)$ & $113.4(6)$ & $114.1(2)$ & $113.61(9)$ & $113.29(16)$ & $113.9(2)$ & $113.8(2)$ \\
\hline \multicolumn{2}{|c|}{$\mathrm{N}(2)-\mathrm{C}(1)-\mathrm{N}(4)$} & $126.7(8)$ & $127.1(3)$ & $127.41(12)$ & $126.1(2)$ & $125.4(3)$ & $124.8(3)$ \\
\hline
\end{tabular}


Table 3 Values of the density of all electrons $-\rho(r)$, Laplacian of electron density $-\nabla^{2} \rho(r)$, energy density $-H_{\mathrm{b}}$, potential energy density $-V(r)$, and Lagrangian kinetic energy $-G(r)$ (hartree) at the bond critical points $(3,-1)$, corresponding to metallophilic interactions $\mathrm{Ni} \ldots \mathrm{Ni}$ in $\mathbf{5 - 1 0 0}$ and $5-\mathrm{RT}$, as well as energies of these interactions $E_{\text {int }}\left(\mathrm{kcal} \mathrm{mol}^{-1}\right)$, defined by two approaches

\begin{tabular}{|c|c|c|c|c|c|c|c|}
\hline Method/basis & $\rho(r)$ & $\nabla^{2} \rho(r)$ & $H_{\mathrm{b}}$ & $V(r)$ & $G(r)$ & $E_{\text {int }}{ }^{a}$ & $E_{\text {int }}^{b}$ \\
\hline $\mathrm{M} 06 / 6-311+\mathrm{G}^{*}$ & 0.010 & 0.023 & 0.000 & -0.005 & 0.005 & 1.6 & 1.4 \\
\hline M06/MDF10(Ni) and 6-311+G* (other atoms) & 0.010 & 0.022 & 0.000 & -0.006 & 0.006 & 1.9 & 1.6 \\
\hline \multicolumn{8}{|l|}{ 5-RT } \\
\hline $\mathrm{M} 06 / 6-311+\mathrm{G}^{*}$ & 0.009 & 0.021 & 0.001 & -0.004 & 0.005 & 1.3 & 1.4 \\
\hline M06/DZP-DKH & 0.009 & 0.021 & 0.001 & -0.004 & 0.005 & 1.3 & 1.4 \\
\hline
\end{tabular}
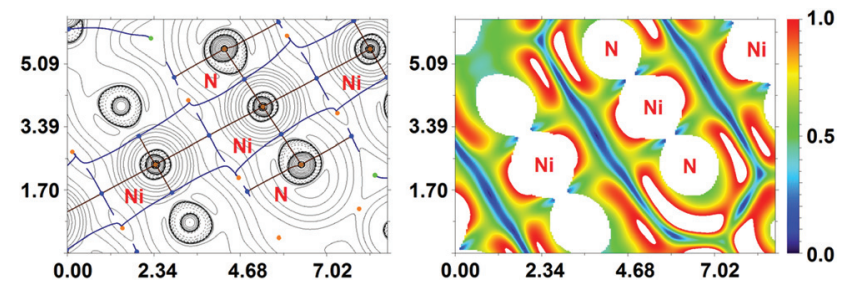

Fig. 2 Contour line diagram of the Laplacian distribution $\nabla^{2} \rho(r)$, bond paths and selected zero-flux surfaces (left) and the RDG isosurface referring to the non-covalent interactions (right) for metallophilic interactions $\mathrm{Ni} \cdots \mathrm{Ni}$ in 5-100 (M06/6-311+G* level of theory). Bond critical points $(3,-1)$ are shown in blue, nuclear critical points $(3,-3)-$ in pale brown, ring critical points $(3,+1)-$ in orange, and cage critical points $(3,+3)$ - in light green. Length is given in units of $\AA$; RDG isosurface values are given in hartree.

studied non-covalent interactions, reduced density gradient (RDG) analysis ${ }^{39}$ was carried out, and the RDG isosurface for 5-100 was plotted (Fig. 2).

The QTAIM analysis demonstrates the presence of appropriate bond critical points (BCPs) for metallophilic interactions $\mathrm{Ni} \cdots \mathrm{Ni}$ both in 5-100 and in 5-RT. The lengths of the corresponding contacts (3.30 $\AA$ for 5-100 and $3.36 \AA$ for 5-RT) are slightly larger than the sum of Bondi's (the shortest) ${ }^{34} \mathrm{vdW}$ radii for $\mathrm{Ni}$ (3.26 $\AA$ ), but noticeably lower than Batsanov's ${ }^{42}$ and Alvarez's ${ }^{35}$ vdW radii for Ni (4.00 and $4.80 \AA$ A, respectively). The low magnitude of the electron density (0.009-0.010 hartree), positive values of the Laplacian (0.021-0.023 hartree), and zero or close to zero (0.001 hartree) positive energy density in these BCPs are typical for noncovalent interactions.

We have defined energies for these contacts according to the procedures proposed by Espinosa et al. ${ }^{40}$ and Vener et $a l^{41}$ (Table 3). The estimated strength of these non-covalent interactions is $1.3-1.9 \mathrm{kcal} \mathrm{mol}^{-1}$. It is noteworthy that previously ${ }^{9}$ we studied relevant $\mathrm{Ni} \cdot \mathrm{Ni}$ intramolecular metallophilic interactions in the dinuclear $\left[\mathrm{Ni}_{2}\left(\mu_{2}-\mathrm{Ph}_{2} \mathrm{Pz}\right)_{2}\right.$ (1,3,5-triazapentadienate $)_{2}$ ] species that were stronger (the estimated energy is 3.5-4.4 kcal $\mathrm{mol}^{-1}$ ). The balance between the Lagrangian kinetic energy $G(r)$ and potential energy density $V(r)$ at the BCPs reveals the nature of these interactions in 5: if the ratio

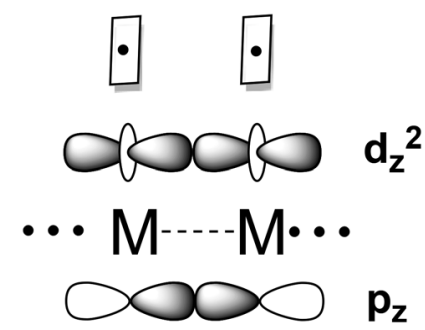

Fig. 3 Weak attractive interactions between the adjacent metal centers due to the overlapping of their $d_{z^{2}}$ and $p_{z}$ orbitals.

$-G(r) / V(r)>1$ is satisfied, then the nature of appropriate interactions is purely non-covalent; in case the ratio $-G(r) / V(r)<1$, some covalent component is observed. ${ }^{43}$ Based on this criterion one can state that the covalent contribution is absent for metallophilic interactions $\mathrm{Ni} \cdots \mathrm{Ni}$ both in 5-100 and in 5-RT. The estimate of the properties of electron density in BCPs and energies for the metallophilic interactions $\mathrm{Ni} \cdots \mathrm{Ni}$ in 5-100 and 5-RT is almost independent of the basis set used (non-relativistic or relativistic approaches).

We believe that in 5 the emergence of nickel(II) $\cdots$ nickel(II) contacts is determined by crystal packing effects and weak attractive interactions between the adjacent metal centers due to the overlapping of their $\mathrm{d}_{z^{2}}$ and $\mathrm{p}_{z}$ orbitals (Fig. 3).

The results of our combined DFT and QTAIM studies reveal that theoretically determined energies for the ligandsupported $^{9}$ and ligand-unsupported (this work) metallophilic interactions nickel(II) $\cdots$ nickel(II) are certainly lower than those found for the $\mathrm{Pd}^{\mathrm{II}} \ldots \mathrm{Pd}^{\mathrm{II}}\left(4.3-6.0 \mathrm{kcal} \mathrm{mol}^{-1}\right.$ (ref. 44)) and $\mathrm{Pt}^{\mathrm{II}} \ldots \mathrm{Pt}^{\mathrm{II}}$ (3.9-11.7 $\mathrm{kcal}^{\mathrm{mol}}{ }^{-1}$ (ref. 45)) systems, and the strength of metallophilic interactions for compounds of group 10 elements logically increases on going down the group.

\section{Concluding remarks}

The results of this work can be considered from a few perspectives. Firstly, we observed an unusual transformation in the system $\mathrm{NiCl}_{2} \cdot 2 \mathrm{H}_{2} \mathrm{O} / \mathrm{NCNR}_{2} / \mathrm{MeC}(=\mathrm{NOH}) \mathrm{NH}_{2}$ in methanol leading to the nitrosoguanidinate complexes $\left[\mathrm{Ni}\left\{\underline{\mathrm{NH}}=\mathrm{C}\left(\mathrm{NR}_{2}\right)\right.\right.$ 
$\left.\mathrm{NN}(\mathrm{O})\}_{2}\right]$. Although the achieved yields are rather low and this reaction at present cannot be recommended for synthetic purposes, the observed transformation explicitly demonstrates that nitrosoguanidinate metal species can be obtained from stable and broadly commercially available precursors, thus avoiding the utilization of toxic (for high toxicity of $\mathrm{N}$-nitroso species, see ref. 46) and explosive nitrosoguanidines for sequestering metal centers.

Secondly, to our knowledge, the coordination chemistry of nitrosoguanidine/ate species is at a very early stage of growth, and metal nitrosoguanidinate derivatives are currently represented exclusively by the $\left[\mathrm{M}\left\{\underline{\mathrm{NH}}=\mathrm{C}\left(\mathrm{NH}_{2}\right) \mathrm{NN}(\mathrm{O})\right\}_{2}\right]$ $(\mathrm{M}=\mathrm{Ni}, \quad \mathrm{Pd}), \quad\left[\mathrm{Co}\left\{\underline{\mathrm{NH}}=\mathrm{C}\left(\mathrm{NH}_{2}\right) \mathrm{NN}(\mathrm{O})\right\}_{2}\left(\mathrm{NH}_{2} \mathrm{CON}_{2} \mathrm{O}\right)\right]$, and $\left[\mathrm{Cu}\left\{\underline{\mathrm{NH}}=\mathrm{C}\left(\mathrm{NH}_{2}\right) \mathrm{NN}(\mathrm{O})\right\}_{2}\right] \cdot \mathrm{Me}_{2} \mathrm{SO}$ complexes that were obtained by the reaction of pre-prepared nitrosoguanidine $\left(\mathrm{H}_{2} \mathrm{NC}(=\mathrm{NH})\right.$ $\mathrm{NHNO}^{25}$ ) with appropriate metal salts. ${ }^{30}$ The years that had passed since the preparation of these complexes did not bring any further nitrosoguanidinate metal compounds. In this work, we present a novel route to metal nitrosoguanidinates and we hope that, after further development, it might represent a method for the generation of nitrosoguanidinate metal species from rather safe precursors and for the further elaboration of nitrosoguanidine coordination chemistry.

Thirdly, we observed a novel difference in reactivity between conventional nitriles and cyanamides that typifies the family of so-called push-pull nitriles.

Finally, the retrosynthetic approach to the obtained nitrosoguanidinate species suggests that these complexes could be generated via metal-mediated coupling between nitrosyl ligands and guanidines. This reaction should be relevant to the reported coupling between the amidinate ligands in $\left[\mathrm{Fe}\{\mathrm{RNC}(\mathrm{Me}) \mathrm{NR}\}_{3}\right]$ and $\mathrm{NO}^{22}$ that leads to the $[\mathrm{Fe}\{\mathrm{N}(=\mathrm{O}) \mathrm{N}(\mathrm{R}) \mathrm{C}$ (Me)NR $\}\left\{\mathrm{RNC}(\mathrm{Me}) \mathrm{NR}_{\}_{2}}\right]$ complex (52\% yield) formed through the nitrosyl-amidinate integration at the iron center. As a further development of the project, we intend to study nitrosyl-guanidinate coupling involving, on the one hand, complexes featuring linear and/or bent nitrosyl ligands and, on the other hand, various $\mathrm{N}$-substituted guanidines. Further studies directed toward widening the family of metal nitrosoguanidinates and establishment of their relevance to our nitroso- ${ }^{47}$ and dinitrosoalkane ${ }^{48}$ ligand systems are in progress in our group.

\section{Experimental section}

\section{Materials and instrumentation}

All dialkylcyanamides, nickel(II) salts and solvents were purchased from commercial sources and used as received. Nickel (II) chloride dihydrate was prepared according to the reported procedure. ${ }^{49}$ The amidoximes $\mathrm{R}^{\prime} \mathrm{C}(=\mathrm{NOH}) \mathrm{NH}_{2} \quad\left(\mathrm{R}^{\prime}=\mathrm{Me}\right.$, $\mathrm{PhCH}_{2}, \mathrm{Ph}, p-\mathrm{BrC}_{6} \mathrm{H}_{4}$ ) were synthesized according to literature methods. ${ }^{50}$ Microanalyses $(\mathrm{C}, \mathrm{H}, \mathrm{N})$ were carried out on a Euro EA3028-HT analyzer. Electrospray ionization mass spectra were obtained on a Bruker micrOTOF spectrometer equipped with an electrospray ionization (ESI) source. The instrument was operated in positive ion mode using an $\mathrm{m} / \mathrm{z}$ range of 50-3000. The capillary voltage of the ion source was set at $-4500 \mathrm{~V}$ (HRESI ${ }^{+}$-MS) and the capillary exit at $+100 \mathrm{~V}$. For HRESI ${ }^{+}$-MS the complexes were dissolved in $\mathrm{MeOH}$ and $\mathrm{MeCN}$ was used as an ionization agent. The absorption spectra were recorded on a Shimadzu UV 1800 spectrophotometer in $\mathrm{CH}_{2} \mathrm{Cl}_{2}$. FTIR spectra were recorded on Shimadzu FTIR-8400S $\left(4000-400 \mathrm{~cm}^{-1}\right)$ and Shimadzu IRAffinity-1S $\left(4000-300 \mathrm{~cm}^{-1}\right)$ spectrometers using KBr pellets. ${ }^{1} \mathrm{H}$ and ${ }^{13} \mathrm{C}\left\{{ }^{1} \mathrm{H}\right\}$ NMR (400.13 and $100.613 \mathrm{MHz}$, respectively) spectra were recorded on a Bruker Avance 400 spectrometer in $\mathrm{Me}_{2} \mathrm{SO}-d_{6}$ and $\mathrm{CDCl}_{3}$ at ambient temperature; residual solvent signals were used as the internal standard (Fig. S19-S20, S25-S26, S31-S32, S37-S38, S43-S44, S49-S50 and S55-S56; ESI†). TG/DTA measurements (Fig. S21, S27, S33, S39, S45, S51 and S57; ESI†) were performed with a NETZSCH TG 209 F1 Libra thermoanalyzer and $\mathrm{MnO}_{2}$ powder was used as a standard. The initial weights of the samples were in the range $0.6-1.6 \mathrm{mg}$. The experiments were run in an open alumina crucible in a stream of argon at a heating rate of $10 \mathrm{~K} \mathrm{~min}^{-1}$. The final temperature of the experiments was $600{ }^{\circ} \mathrm{C}$. Analysis of thermal data was performed with Proteus analysis software.

\section{$\mathrm{X}$-ray diffraction}

Single-crystal XRD experiment was carried out on Agilent Technologies "Xcalibur" and "SuperNova" diffractometers with monochromated MoK $\alpha$ and $\mathrm{CuK} \alpha$ radiation sources, respectively. The crystal was kept at 100(2) K during experiment. The structures were solved by means of the Superflip ${ }^{51}$ structure solution program using Charge Flipping and refined by means of the ShelXL ${ }^{52}$ program incorporated into the OLEX2 program package. ${ }^{53}$ Empirical absorption corrections were applied using the CrysAlisPro (Agilent Technologies, 2012) program package using spherical harmonics implemented in SCALE3 ABSPACK scaling algorithm. CCDC numbers 1530060 and $1530062-1530064 \dagger$ contain the supplementary crystallographic data for the structures.

\section{Computational details}

Single point calculations based on the experimental X-ray geometries of 5-100 and 5-RT (quasi-solid-state approach) were carried out at the DFT level of theory using the M06 functional $^{54}$ (this functional was specifically developed to describe weak dispersion forces and non-covalent interactions) with the help of the Gaussian- $09^{55}$ program package. Three approaches were used, viz. (i) the Douglas-Kroll-Hess $2^{\text {nd }}$ order scalar relativistic calculations ${ }^{56}$ that requested a relativistic core Hamiltonian were carried out using DZP-DKH basis sets ${ }^{57}$ for all atoms; (ii) the effective core potential calculations were carried out using the multielectron fit fully relativistic energyconsistent pseudopotential MDF10 of the Stuttgart/Cologne group that described 10 core electrons and the appropriate contracted basis set for the nickel atom ${ }^{58}$ and the standard $6-311+G^{*}$ basis sets for other atoms; (iii) the non-relativistic calculations were carried out using the standard $6-311+\mathrm{G}^{*}$ basis sets for all atoms. The topological analysis of the electron 
density distribution with the help of the atoms in molecules (QTAIM) method developed by Bader ${ }^{37}$ was performed using the Multiwfn program (version 3.3.8). ${ }^{59}$ The full geometry optimization procedure was carried out with the help of the Gaussian-09 ${ }^{55}$ program package at the CAM-B3LYP/ $6-311++G^{* *}$ (for 1 in dichloromethane solution) and M06/ 6-311+G* (for 1, 3, 4, and 5 in gas phase) levels of theory. No symmetry restrictions have been applied during the geometry optimization and experimental X-ray data were used as starting points. The solvent effects were taken into account using the SMD continuum solvation model of Truhlar et al. ${ }^{60}$ The Hessian matrix was calculated analytically for all optimized structures in order to prove the location of correct minima (no imaginary frequencies). The Cartesian atomic coordinates of model structures are presented in Table S3 (ESI $\dagger$ ).

\section{Synthetic work}

$\mathrm{Ni}^{\mathrm{II}}$-Mediated reaction of dimethylcyanamide with amidoximes: generation of 1-7. $\mathrm{MeC}(=\mathrm{NOH}) \mathrm{NH}_{2}(7.4 \mathrm{mg}, 0.1 \mathrm{mmol})$ powder was added to a stirred suspension of $\mathrm{NiCl}_{2} \cdot 2 \mathrm{H}_{2} \mathrm{O}$ (40 mg, $0.24 \mathrm{mmol})$ in $\mathrm{MeOH}(15 \mathrm{~mL})$ placed in a $20 \mathrm{~mL}$ round bottomed flask. Then any one of the corresponding cyanamides $\mathrm{NCNR}_{2}\left(\mathrm{R}_{2}=\mathrm{Me}_{2},\left(\mathrm{CH}_{2}\right)_{4} \mathrm{O},\left(\mathrm{CH}_{2}\right)_{4},\left(\mathrm{CH}_{2}\right)_{5},(\mathrm{Me}) \mathrm{Ph}\right.$, $\left.\mathrm{Ph}_{2},\left(p-\mathrm{MeC}_{6} \mathrm{H}_{4}\right)_{2} ; 0.6 \mathrm{mmol}\right)$ was added to the mixture and it was left to stand for $24 \mathrm{~h}$ at $50{ }^{\circ} \mathrm{C}$ in the closed flask without stirring. The color of the homogeneous solution turned from light green to dark brown or dark violet $\left(\mathrm{R}_{2}=\mathrm{Ph}_{2}\right)$. The resulting solutions were evaporated in open air at RT, furnishing, after 2-3 d, crystalline precipitates of 1-7 along with the released oily residues of other Ni-containing products. The precipitates formed were separated from the oily residues by washing with three $1.5 \mathrm{~mL}$ portions of $\mathrm{MeOH}$ and dried in a desiccator over $\mathrm{CaCl}_{2}$ at RT.

$\left[N i\left\{\underline{N} H=C\left(\mathrm{NMe}_{2}\right) N \underline{N}(\mathrm{O})\right\}_{2}\right]$ (1). $10.7 \mathrm{mg}, 15 \%$. Red needles. Anal. calcd for $\mathrm{C}_{6} \mathrm{H}_{14} \mathrm{~N}_{8} \mathrm{NiO}_{2}$ : C, 24.94; $\mathrm{H}, 4.88 ; \mathrm{N}, 38.78$. Found: C, 25.01; H, 4.88, N, 38.77\%. $\mathrm{HRESI}^{+}, \mathrm{m} / \mathrm{z}: 289.0674$ $\left([\mathrm{M}+\mathrm{H}]^{+}\right.$requires 289.0671), $311.0496\left([\mathrm{M}+\mathrm{Na}]^{+}\right.$requires 311.0491), $599.1078\left([2 \mathrm{M}+\mathrm{Na}]^{+}\right.$requires 599.1084), 889.1634 $\left([3 \mathrm{M}+\mathrm{Na}]^{+}\right.$requires 889.1632). $\nu_{\max }(\mathrm{KBr}) / \mathrm{cm}^{-1}: 3374 \mathrm{~m}$, $\nu(\mathrm{N}-\mathrm{H}) ; 2936 \mathrm{w}, \nu(\mathrm{C}-\mathrm{H}) ; 2886 \mathrm{w}, \nu(\mathrm{C}-\mathrm{H}) ; 1608 \mathrm{~s} \nu(\mathrm{C}=\mathrm{N}), 1386 \mathrm{~s}$ $\nu(\mathrm{N}=\mathrm{O}) .{ }^{1} \mathrm{H}$ NMR $\left(\mathrm{CDCl}_{3}, \delta\right): 3.05\left(\mathrm{~s}, 6 \mathrm{H}, \mathrm{CH}_{3}\right), 3.19(\mathrm{~s}, 6 \mathrm{H}$, $\left.\mathrm{CH}_{3}\right), 3.72(\mathrm{~s}, 1 \mathrm{H}, \mathrm{NH}), 3.75(\mathrm{~s}, 1 \mathrm{H}, \mathrm{NH}) .{ }^{13} \mathrm{C}\left\{{ }^{1} \mathrm{H}\right\} \mathrm{NMR}\left(\mathrm{CDCl}_{3}, \delta\right)$ : 37.20 and $40.47\left(\mathrm{CH}_{3}\right), 167.20(\mathrm{~N}(\mathrm{H})=C)$. On heating in a capillary $\left(2^{\circ} \mathrm{min}^{-1}\right)$ this complex turns brown and decomposes at $270-272{ }^{\circ} \mathrm{C}$. TG/DTA: $210-244{ }^{\circ} \mathrm{C}$ (weight loss $34.7 \%$; $\mathrm{NH}_{2} \mathrm{CONMe}_{2}$, requires $34.9 \%$ ), 244-609 ${ }^{\circ} \mathrm{C}$ (weight loss $43.2 \%$; $75.5 \% \mathrm{NiO}$, requires $74.7 \%$ ). Crystals suitable for XRD were obtained from the reaction mixture by its slow evaporation.

$\left[\mathrm{Ni}\left\{\underline{N} H=C\left(\mathrm{NC}_{4} \mathrm{H}_{8} \mathrm{O}\right) \mathrm{N} \underline{\mathrm{N}}(\mathrm{O})\right\}_{2}\right]$ (2). $10.4 \mathrm{mg}, 12 \%$. Red powder. Anal. calcd for $\mathrm{C}_{10} \mathrm{H}_{18} \mathrm{~N}_{8} \mathrm{NiO}_{4}$ : C, 32.20; H, 4.86; N, 30.04. Found: C, 32.29; H, 4.82, N, 30.00\%. $\mathrm{HRESI}^{+}, \mathrm{m} / \mathrm{z}: 113.0713$ $\left(\left[\mathrm{NCNC}_{4} \mathrm{H}_{8} \mathrm{OH}\right]^{+}\right.$requires 113.0715), $373.0886\left([\mathrm{M}+\mathrm{H}]^{+}\right.$ requires 373.0883), $395.0702\left([\mathrm{M}+\mathrm{Na}]^{+}\right.$requires 395.0702), $767.1516\left([2 \mathrm{M}+\mathrm{Na}]^{+}\right.$requires 767.1507$) \cdot \nu_{\max }(\mathrm{KBr}) / \mathrm{cm}^{-1}: 3403$ w, $\nu(\mathrm{N}-\mathrm{H}) ; 2983 \mathrm{w}, \nu(\mathrm{C}-\mathrm{H}) ; 2921 \mathrm{w}, \nu(\mathrm{C}-\mathrm{H}) ; 2867 \mathrm{w}, \nu(\mathrm{C}-\mathrm{H})$; $1599 \mathrm{~s}, \nu(\mathrm{C}=\mathrm{N}) ; 1414 \mathrm{~s}, \nu(\mathrm{N}=\mathrm{O}) .{ }^{1} \mathrm{H}$ NMR $\left(D_{M S O}-d_{6}, \delta\right)$ :
3.52-3.55 (m, $\left.4 \mathrm{H}, \mathrm{CH}_{2}{ }^{\alpha}\right), 3.61-3.64\left(\mathrm{~m}, 4 \mathrm{H}, \mathrm{CH}_{2}{ }^{\beta}\right), 4.65(\mathrm{~s}, 2 \mathrm{H}$, $\mathrm{NH}) .{ }^{13} \mathrm{C}\left\{{ }^{1} \mathrm{H}\right\}$ NMR (DMSO- $\left.d_{6}, \delta\right): 48.46\left(\mathrm{OCH}_{2}\right), 65.50\left(\mathrm{NCH}_{2}\right)$, the $\mathrm{N}(\mathrm{H})=C$ signal was not detected. On heating in a capillary $\left(2^{\circ} \mathrm{min}^{-1}\right)$ this complex turns brown and decomposes at 284-285 ${ }^{\circ} \mathrm{C}$. TG/DTA: 220-299 ${ }^{\circ} \mathrm{C}$ (weight loss 53.9\%), 299-610 ${ }^{\circ} \mathrm{C}$ (weight loss 19.9\%).

$\left[N i\left\{\underline{N} H=C\left(N C_{5} H_{10}\right) N \underline{N}(O)\right\}_{2}\right]$ (3). $10.3 \mathrm{mg}, 12 \%$. Red needles. Anal. calcd for $\mathrm{C}_{12} \mathrm{H}_{22} \mathrm{~N}_{8} \mathrm{NiO}_{2}$ : C, 39.05; $\mathrm{H}, 6.01 ; \mathrm{N}, 30.36$. Found: C, 39.03; H, 6.15, N, 30.22\%. $\mathrm{HRESI}^{+}, \mathrm{m} / \mathrm{z}: 369.1315$ $\left(\left[\mathrm{Ni}\left\{\mathrm{NHC}\left(\mathrm{NC}_{5} \mathrm{H}_{10}\right) \mathrm{NN}(\mathrm{O})\right\}_{2} \mathrm{H}\right]^{+}\right.$requires 369.1297$), 391.1126$ $\left([\mathrm{M}+\mathrm{Na}]^{+}\right.$requires 391.1117), $759.2321\left([2 \mathrm{M}+\mathrm{Na}]^{+}\right.$requires 759.2336), $1129.3452\left([3 \mathrm{M}+\mathrm{Na}]^{+}\right.$requires 1129.3510). $\nu_{\max }(\mathrm{KBr}) / \mathrm{cm}^{-1}: 3362 \mathrm{~m}, \nu(\mathrm{N}-\mathrm{H}) ; 2936 \mathrm{w}, \nu(\mathrm{C}-\mathrm{H}) ; 2850 \mathrm{w}$, $\nu(\mathrm{C}-\mathrm{H}) ; 1596 \mathrm{~s}, \nu(\mathrm{C}=\mathrm{N}) ; 1404 \mathrm{~s}, \nu(\mathrm{N}=\mathrm{O}) .{ }^{1} \mathrm{H}$ NMR (DMSO- $d_{6}$,

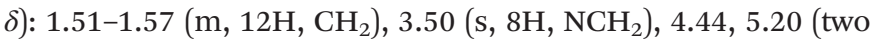
s, $2 \mathrm{H}, \mathrm{NH}) .{ }^{13} \mathrm{C}\left\{{ }^{1} \mathrm{H}\right\} \mathrm{NMR}\left(\mathrm{CDCl}_{3}, \delta\right): 23.92,25.79\left(\mathrm{CH}_{2}\right), 46.25$, $48.95\left(\right.$ br $\left.\mathrm{NCH}_{2}\right), 165.59(\mathrm{~N}(\mathrm{H})=C)$. On heating in a capillary $\left(2^{\circ} \mathrm{min}^{-1}\right)$ this complex turns brown and decomposes at 255-256 ${ }^{\circ} \mathrm{C}$. TG/DTA: 204-295 ${ }^{\circ} \mathrm{C}$ (weight loss 63.9\%), 295-610 ${ }^{\circ} \mathrm{C}$ (weight loss $16.8 \%$ ). Crystals suitable for XRD were obtained from the reaction mixture by its slow evaporation.

$\left[N i\left\{\underline{N} H=C\left(N C_{4} H_{8}\right) N \underline{N}(O)\right\}_{2}\right]$ (4). $10.5 \mathrm{mg}, 13 \%$. Red needles. Anal. calcd for $\mathrm{C}_{10} \mathrm{H}_{18} \mathrm{~N}_{8} \mathrm{NiO}_{2}$ : C, 35.22; $\mathrm{H}, 5.32 ; \mathrm{N}, 32.86$. Found: C, 35.02; H, 5.25; N, 32.60\%. $\mathrm{HRESI}^{+}, \mathrm{m} / \mathrm{z}: 341.1003$ $\left([\mathrm{M}+\mathrm{H}]^{+}\right.$requires 341.0984), $363.0836\left([\mathrm{M}+\mathrm{Na}]^{+}\right.$requires 363.0804), $703.1764\left([2 \mathrm{M}+\mathrm{Na}]^{+}\right.$requires 703.1710$), 1045.2612$ $\left([3 \mathrm{M}+\mathrm{Na}]^{+}\right.$requires 1045.2571). $\nu_{\max }(\mathrm{KBr}) / \mathrm{cm}^{-1}: 3352 \mathrm{~m}$, $\nu(\mathrm{N}-\mathrm{H}) ; 2954 \mathrm{w}, \nu(\mathrm{C}-\mathrm{H}) ; 2876 \mathrm{w}, \nu(\mathrm{C}-\mathrm{H}) ; 1600 \mathrm{~s}, \nu(\mathrm{C}=\mathrm{N})$; $1396 \mathrm{~m}, \nu(\mathrm{N}=\mathrm{O}) .{ }^{1} \mathrm{H}$ NMR $\left(\mathrm{CDCl}_{3}, \delta\right): 1.94\left(\mathrm{~m}, 4 \mathrm{H}, \mathrm{CH}_{2}\right), 2.05$ $\left(\mathrm{m}, 4 \mathrm{H}, \mathrm{CH}_{2}\right), 3.38\left(\mathrm{~m}, 4 \mathrm{H}, \mathrm{NCH}_{2}\right), 3.55(\mathrm{~s}, 2 \mathrm{H}, \mathrm{NH}), 3.61(\mathrm{~m}$, $\left.4 \mathrm{H}, \mathrm{NCH}_{2}\right) .{ }^{13} \mathrm{C}\left\{{ }^{1} \mathrm{H}\right\} \mathrm{NMR}\left(\mathrm{CDCl}_{3}, \delta\right): 25.13,25.74\left(\mathrm{CH}_{2}\right), 46.15$, $49.58\left(\mathrm{NCH}_{2}\right), 164.91(\mathrm{~N}(\mathrm{H})=C)$. TG/DTA: $212-322{ }^{\circ} \mathrm{C}$ (weight loss $57.1 \%$ ), $322-484{ }^{\circ} \mathrm{C}$ (weight loss $10.5 \%$ ). Crystals suitable for XRD were obtained from the reaction mixture by its slow evaporation.

$\left[N i\left\{\underline{N} H=C\left(N\left(\mathrm{CH}_{3}\right) P h\right) N \underline{N}(\mathrm{O})\right\}_{2}\right] \quad$ (5). $15.3 \mathrm{mg}, \quad 15 \%$. Red needles. Anal. calcd for $\mathrm{C}_{16} \mathrm{H}_{18} \mathrm{~N}_{8} \mathrm{NiO}_{2}$ : C, 46.52; H, 4.39; $\mathrm{N}, 27.13$. Found: C, 46.57; H, 4.50, N, 27.22\%. HRESI ${ }^{+}, \mathrm{m} / \mathrm{z}$ : $413.0977\left([\mathrm{M}+\mathrm{H}]^{+}\right.$requires 413.0984), $435.0800\left([\mathrm{M}+\mathrm{Na}]^{+}\right.$ requires 435.0804), $847.1708\left([2 \mathrm{M}+\mathrm{Na}]^{+}\right.$requires 847.1710). $\nu_{\max }(\mathrm{KBr}) / \mathrm{cm}^{-1}: 3394 \mathrm{~m}, \nu(\mathrm{N}-\mathrm{H}) ; 3050 \mathrm{w}, \nu(\mathrm{C}-\mathrm{H}) ; 2928 \mathrm{w}$, $\nu(\mathrm{C}-\mathrm{H}) ; 1608 \mathrm{~s}, \nu(\mathrm{C}=\mathrm{N}) ; 1578 \mathrm{~s}, \nu(\mathrm{CN})$ and/or $\delta\left(\mathrm{CH}_{\mathrm{Ar}}\right), 1496 \mathrm{~m}$, $\nu(\mathrm{Ph}), 1392 \mathrm{~s}, \nu(\mathrm{N}=\mathrm{O}) .{ }^{1} \mathrm{H}$ NMR (DMSO- $\left.d_{6}, \delta\right): 3.36(\mathrm{~s}, 6 \mathrm{H}$, $\mathrm{CH}_{3}$ ), 4.11, 5.38 (two s, 2H, NH), $7.13(\mathrm{~m}, 6 \mathrm{H}, \mathrm{Ph}), 7.47(\mathrm{~m}, 4 \mathrm{H}$, $\mathrm{Ph}) .{ }^{13} \mathrm{C}\left\{{ }^{1} \mathrm{H}\right\}$ NMR $\left(\mathrm{CDCl}_{3}, \delta\right): 41.34\left(\mathrm{CH}_{3}\right), 126.47,128.70$, $130.56\left(\mathrm{CH}_{\mathrm{Ar}}\right) ; 141.73\left(\mathrm{C}_{i p s o}\right), 167.02(\mathrm{~N}(\mathrm{H})=C)$. On heating in a capillary $\left(2^{\circ} \mathrm{min}^{-1}\right)$ this complex turns brown and decomposes at $259-260{ }^{\circ} \mathrm{C}$. TG/DTA: $215-452{ }^{\circ} \mathrm{C}$ (weight loss $59.7 \%$ ), $452-609^{\circ} \mathrm{C}$ (weight loss $5.7 \%$ ). Crystals suitable for XRD were obtained from the reaction mixture by its slow evaporation.

$\left[N i\left\{\underline{N} H=C\left(N P h_{2}\right) N \underline{N}(O)\right\}_{2}\right]$ (6). $33.1 \mathrm{mg}, 26 \%$. Purple thin needles. Anal. calcd for $\mathrm{C}_{26} \mathrm{H}_{22} \mathrm{~N}_{8} \mathrm{NiO}_{2}$ : C, 58.13; $\mathrm{H}, 4.13 ; \mathrm{N}$, 20.86. Found: C, 58.03; H, 4.50, N, 20.22\%. $\mathrm{HRESI}^{+}, \mathrm{m} / \mathrm{z}$ : $537.1295\left([\mathrm{M}+\mathrm{H}]\right.$ requires 537.1297), $559.1116\left([\mathrm{M}+\mathrm{Na}]^{+}\right.$ requires 559.1117), $1095.2397\left([2 \mathrm{M}+\mathrm{Na}]^{+}\right.$requires 1095.2336). $\nu_{\max }(\mathrm{KBr}) / \mathrm{cm}^{-1}: 3476 \mathrm{w}, \nu(\mathrm{N}-\mathrm{H}) ; 3394 \mathrm{w}, \nu(\mathrm{N}-\mathrm{H}), 3060 \mathrm{w}$, 
$\nu(\mathrm{C}-\mathrm{H}) ; 1566 \mathrm{~s}, \nu(\mathrm{C}=\mathrm{N}) ; 1492 \mathrm{~m} \delta\left(\mathrm{CH}_{\mathrm{Ar}}\right) ; 1392 \mathrm{~s}, \nu(\mathrm{N}=\mathrm{O}) .{ }^{1} \mathrm{H}$ NMR $\left(\mathrm{CDCl}_{3}, \delta\right): 4.43$ (s, 2H, NH), $7.30(\mathrm{~m}, 20 \mathrm{H}, \mathrm{Ph}) .{ }^{13} \mathrm{C}\left\{{ }^{1} \mathrm{H}\right\}$ NMR $\left(\mathrm{CDCl}_{3}, \delta\right): 127.30,127.99,129.93\left(\mathrm{CH}_{\mathrm{Ar}}\right), 142.08\left(\mathrm{C}_{\text {ipso }}\right)$, $167.2(\mathrm{~N}(\mathrm{H})=C)$. On heating in a capillary $\left(2^{\circ} \mathrm{min}^{-1}\right)$ this complex turns brown and decomposes at $284-285^{\circ} \mathrm{C}$. TG/DTA: 240-262 ${ }^{\circ} \mathrm{C}$ (weight loss 8.6\%), 262-276 ${ }^{\circ} \mathrm{C}$ (weight loss $27.5 \%$ ), 276-324 ${ }^{\circ} \mathrm{C}$ (weight loss $28.3 \%$ ), 324-610 ${ }^{\circ} \mathrm{C}$ (weight loss $10.1 \%)$.

$\left[\mathrm{Ni}\left\{\underline{\mathrm{NH}}=\mathrm{C}\left(\mathrm{N}(\mathrm{p}-\mathrm{Tol})_{2}\right) \mathrm{N} \underline{N}(\mathrm{O})\right\}_{2}\right]$ (7). $33.8 \mathrm{mg}, 24 \%$. Purple thin needles. Anal. calcd for $\mathrm{C}_{30} \mathrm{H}_{30} \mathrm{~N}_{8} \mathrm{NiO}_{2}$ : C, 60.73; H, 5.10; N, 18.89. Found: C, 59.95; H, 5.50, N, 19.22\%. HRESI ${ }^{+}, m / z$ : $593.1933\left([\mathrm{M}+\mathrm{H}]^{+}\right.$requires 593.1923), $1185.3823\left([2 \mathrm{M}+\mathrm{H}]^{+}\right.$ requires 1185.3769). $\nu_{\max }(\mathrm{KBr}) / \mathrm{cm}^{-1}: 3394 \mathrm{~m}, \nu(\mathrm{N}-\mathrm{H}) ; 3034 \mathrm{w}$, $\nu(\mathrm{C}-\mathrm{H}), 3062 \mathrm{w}, \nu(\mathrm{C}-\mathrm{H}) ; 2920 \mathrm{w}, \nu(\mathrm{C}-\mathrm{H}) ; 1570 \mathrm{~s}, \nu(\mathrm{C}=\mathrm{N})$; $\delta\left(\mathrm{CH}_{\mathrm{Ar}}\right) ; 1390 \mathrm{~s}, \nu(\mathrm{N}=\mathrm{O}) .{ }^{1} \mathrm{H}$ NMR $\left(\mathrm{CDCl}_{3}, \delta\right): 2.32(\mathrm{~s}, 12 \mathrm{H}$, $\left.\mathrm{CH}_{3}\right), 4.33$ (s, 2H, NH), 7.08-7.13 (d, 16H, CH $\left.\mathrm{Ar}\right) .{ }^{13} \mathrm{C}\left\{{ }^{1} \mathrm{H}\right\} \mathrm{NMR}$ $\left(\mathrm{CDCl}_{3}, \delta\right): 21.19\left(\mathrm{CH}_{3}\right), 126.31\left(\mathrm{C}_{\text {ipso }}\right), 126.92,130.48\left(\mathrm{CH}_{\mathrm{Ar}}\right)$, $137.07\left(\mathrm{C}_{\text {ipso }}\right), 167.25(\mathrm{~N}(\mathrm{H})=C)$. On heating in a capillary $\left(2^{\circ} \mathrm{min}^{-1}\right)$ this complex turns purple and decomposes at 289-290 ${ }^{\circ} \mathrm{C}$. TG/DTA: 214-349 ${ }^{\circ} \mathrm{C}$ (weight loss 62.6\%), 349-569 ${ }^{\circ} \mathrm{C}$ (weight loss 9.1\%).

\section{Acknowledgements}

The authors are grateful to the Russian Science Foundation (grant 14-13-0060). Physicochemical studies were performed at the Center for Magnetic Resonance, Center for X-ray Diffraction Studies, Center for Chemical Analysis and Materials Research, and the Center for Thermogravimetric and Calorimetric Research (all belonging to Saint Petersburg State University). The authors thank the reviewers for valuable suggestions.

\section{References}

1 N. A. Bokach and V. Y. Kukushkin, Coordination chemistry of dialkylcyanamides: Binding properties, synthesis of metal complexes, and ligand reactivity, Coord. Chem. Rev., 2013, 257, 2293-2316.

2 (a) P. V. Gushchin, M. R. Tyan, N. A. Bokach, M. D. Revenco, M. Haukka, M.-J. Wang, C.-H. Lai, P.-T. Chou and V. Y. Kukushkin, Novel tailoring reaction for two adjacent coordinated nitriles giving platinum 1,3,5-triazapentadiene complexes, Inorg. Chem., 2008, 47, 1148711500; (b) P. V. Gushchin, M. L. Kuznetsov, M. Haukka, M.-J. Wang, A. V. Gribanov and V. Y. Kukushkin, A novel reactivity mode for metal-activated dialkylcyanamide species: Addition of $\mathrm{n}, \mathrm{n}$ '-diphenylguanidine to a cis(r2ncn)2ptii center giving an eight-membered chelated platinaguanidine, Inorg. Chem., 2009, 48, 2583-2592; (c) M. F. C. Guedes da Silva, C. M. P. Ferreira, E. M. P. R. P. Branco, J. J. R. Fraústo da Silva, A. J. L. Pombeiro, R. A. Michelin, U. Belluco, R. Bertani, M. Mozzon, G. Bombieri, F. Benetollo and V. Y. Kukushkin,
Bifunctional activation of cyanoguanidine. Synthesis and molecular structure of the azametallacycle cis-[(pph3)2pt $\{$ nhc(ome $)=\mathrm{nc}(\mathrm{nh} 2)=\mathrm{nh}\}][\mathrm{bph} 4]$, Inorg. Chim. Acta, 1997, 265, 267-270.

3 N. A. Bokach, T. B. Pakhomova, V. Y. Kukushkin, M. Haukka and A. J. L. Pombeiro, Hydrolytic metalmediated coupling of dialkylcyanamides at a pt(iv) center giving a new family of diimino ligands, Inorg. Chem., 2003, 42, 7560-7568.

4 K. V. Luzyanin, M. Haukka, N. A. Bokach, M. L. Kuznetsov, V. Y. Kukushkin and A. J. L. Pombeiro, Platinum(iv)mediated hydrolysis of nitriles giving metal-bound iminols, J. Chem. Soc., Dalton Trans., 2002, 1882-1887, DOI: 10.1039/ B108327A.

5 D. S. Bolotin, N. A. Bokach, A. S. Kritchenkov, M. Haukka and V. Y. Kukushkin, Amidrazone complexes from a cascade platinum(ii)-mediated reaction between amidoximes and dialkylcyanamides, Inorg. Chem., 2013, 52, 63786389.

6 D. S. Bolotin, M. Y. Demakova, A. S. Novikov, M. S. Avdontceva, M. L. Kuznetsov, N. A. Bokach and V. Y. Kukushkin, Bifunctional reactivity of amidoximes observed upon nucleophilic addition to metal-activated nitriles, Inorg. Chem., 2015, 54, 4039-4046.

7 M. N. Kopylovich, A. J. L. Pombeiro, A. Fischer, L. Kloo and V. Y. Kukushkin, Facile ni(ii)/ketoxime-mediated conversion of organonitriles into imidoylamidine ligands. Synthesis of imidoylamidines and acetyl amides, Inorg. Chem., 2003, 42, 7239-7248.

8 (a) E. V. Andrusenko, E. V. Kabin, A. S. Novikov, N. A. Bokach, G. L. Starova, A. A. Zolotarev and V. Y. Kukushkin, Highly reactive niii-bound nitrile-oxime coupling intermediates stabilized by substituting conventional nitriles with a dialkylcyanamide, Eur. J. Inorg. Chem., 2015, 2015, 4894-4904; (b) M. N. Kopylovich, A. M. Kirillov, E. A. Tronova, M. Haukka, V. Y. Kukushkin and A. J. L. Pombeiro, 1,3,5-triazapentadiene nickel(ii) complexes derived from a ketoxime-mediated single-pot transformation of nitriles, Eur. J. Inorg. Chem., 2010, 2010, 24252432; (c) M. N. Kopylovich, M. Haukka, A. M. Kirillov, V. Y. Kukushkin and A. J. L. Pombeiro, Novel nickel(ii) complex bearing phthalimido ligands derived from oximemediated transformation of phthalonitrile, Inorg. Chem. Commun., 2008, 11, 117-120; (d) M. N. Kopylovich, M. Haukka, A. M. Kirillov, V. Y. Kukushkin and A. J. L. Pombeiro, Unsymmetrical niii-imidoylamidine complexes derived from a novel oxime-mediated single-pot reaction of nitriles, Chem. - Eur. J., 2007, 13, 786-791; (e) M. N. Kopylovich, E. A. Tronova, M. Haukka, A. M. Kirillov, V. Y. Kukushkin, J. J. R. Fraústo da Silva and A. J. L. Pombeiro, Identification of hexameric water and hybrid water-chloride clusters intercalated in the crystal hosts of (imidoylamidine)nickel(ii) complexes, Eur. J. Inorg. Chem., 2007, 2007, 4621-4627.

9 E. V. Andrusenko, E. V. Kabin, A. S. Novikov, N. A. Bokach, G. L. Starova and V. Y. Kukushkin, Metal-mediated gene- 
ration of triazapentadienate-terminated di- and trinuclear [small mu]2-pyrazolate niii species and control of their nuclearity, New J. Chem., 2017, 41, 316-325.

10 D. S. Bolotin, K. I. Kulish, N. A. Bokach, G. L. Starova, V. V. Gurzhiy and V. Y. Kukushkin, Zinc(ii)-mediated nitrile-amidoxime coupling gives new insights into $\mathrm{h}+-$ assisted generation of 1,2,4-oxadiazoles, Inorg. Chem., 2014, 53, 10312-10324.

11 D. S. Bolotin, N. A. Bokach, M. Haukka and V. Y. Kukushkin, Amidoximes provide facile platinum(ii)-mediated oximenitrile coupling, Inorg. Chem., 2012, 51, 5950-5964.

12 P. Beranova, K. Chalupsky, A. L. Kleschyov, C. Schott, J.-L. Boucher, D. Mansuy, T. Munzel, B. Muller and J.-C. Stoclet, N $\omega$-hydroxy-l-arginine homologues and hydroxylamine as nitric oxide-dependent vasorelaxant agents, Eur. J. Pharmacol., 2005, 516, 260-267.

13 C. Antonino, C. Maria Assunta and P. Venerando, Regeneration of carbonyl compounds from the corresponding oximes: An update until to 2008, Curr. Org. Chem., 2009, 13, 482-501.

14 M. N. Kopylovich and A. J. L. Pombeiro, Coordination chemistry of 1,3,5-triazapentadienes, Chem. Rev., 2011, 255, 339-355.

15 D. S. Bolotin, V. K. Burianova, A. S. Novikov, M. Y. Demakova, C. Pretorius, P. P. Mokolokolo, A. Roodt, N. A. Bokach, V. V. Suslonov, A. P. Zhdanov, K. Y. Zhizhin, N. T. Kuznetsov and V. Y. Kukushkin, Nucleophilicity of oximes based upon addition to a nitrilium closo-decaborate cluster, Organometallics, 2016, 35, 3612-3623.

16 M. N. Kopylovich, V. Y. Kukushkin, M. F. C. Guedes da Silva, M. Haukka, J. J. R. Frausto da Silva and A. J. L. Pombeiro, Conversion of alkanenitriles to amidines and carboxylic acids mediated by a cobalt(ii)-ketoxime system, J. Chem. Soc., Perkin Trans. 1, 2001, 1569-1573, DOI: $10.1039 / \mathrm{B} 101337 \mathrm{H}$.

17 M. N. Kopylovich, V. Y. Kukushkin, M. Haukka, K. V. Luzyanin and A. J. L. Pombeiro, An efficient synthesis of phthalocyanines based on an unprecedented doubleaddition of oximes to phthalonitriles, J. Am. Chem. Soc., 2004, 126, 15040-15041.

18 F. D. Rochon, P. C. Kong and R. Melanson, Hydrolysis and dimerization of nitrile to diacetamide and crystal structures of $\quad$ chloro(2,2,2,2',2',2'-hexachlorodiacetamido)(dimethyl sulfoxide)platinum(ii) and cis-aquadichloro(dimethyl sulfoxide)platinum(ii), Inorg. Chem., 1990, 29, 2708-2712.

19 (a) C. W. Leung, W. Zheng, Z. Zhou, Z. Lin and C. P. Lau, Mechanism of catalytic hydration of nitriles with hydrotris(pyrazolyl)borato (tp) ruthenium complexes, Organometallics, 2008, 27, 4957-4969; (b) T. B. Anisimova, N. A. Bokach, K. V. Luzyanin, M. Haukka and V. Y. Kukushkin, Push-pull nitrile ligands exhibit specific hydration patterns, Dalton Trans., 2010, 39, 10790-10798.

20 M. Emirdag-Eanes and J. A. Ibers, Conversion of a re(iv) tetrahedral cluster to a re(iii) octahedral cluster: Synthesis of $[(\mathrm{ch} 3) \mathrm{c}(\mathrm{nh} 2) 2] 4[\mathrm{re} 6 \mathrm{se} 8(\mathrm{cn}) 6]$ by a solvothermal route, Inorg. Chem., 2002, 41, 6170-6171.
21 A. V. Makarycheva-Mikhailova, P. V. Gushchin, M. N. Kopylovich, I. N. Ganebnykh, V. N. Charushin, M. Haukka, A. J. L. Pombeiro and V. Y. Kukushkin, Ni(ii)mediated nitrosation of oximes bearing an $\alpha$-ch2 group, Inorg. Chem. Commun., 2006, 9, 869-871.

22 J. A. Clark, M. Kilner and A. Pietrzykowski, Amidino-complexes of iron(ii) and (iii), Inorg. Chim. Acta, 1984, 82, 85-92.

23 A. G. Tskhovrebov, E. Solari, R. Scopelliti and K. Severin, Insertion of zerovalent nickel into the $n-n$ bond of n-heterocyclic-carbene-activated n2o, Inorg. Chem., 2013, 52, 11688-11690.

24 A. F. McKay, Nitroguanidines, Chem. Rev., 1952, 51, 301346.

25 R. K. Murmann, R. Glaser and C. L. Barnes, Structures of nitroso- and nitroguanidine x-ray crystallography and computational analysis, J. Chem. Crystallogr., 2005, 35, 317-325.

26 J. Y. Cho, A. Dutton, T. Miller, K. N. Houk and J. M. Fukuto, Oxidation of n-hydroxyguanidines by copper(ii): Model systems for elucidating the physiological chemistry of the nitric oxide biosynthetic intermediate n-hydroxyl-l-arginine, Arch. Biochem. Biophys., 2003, 417, $65-76$.

27 A. Kat, W. G. Thilly, W. H. Fang, M. J. Longley, G. M. Li and P. Modrich, An alkylation-tolerant, mutator human cell line is deficient in strand-specific mismatch repair, Proc. Natl. Acad. Sci. U. S. A., 1993, 90, 6424-6428.

28 A. E. Fogel'zang, B. S. Svetlov, V. Y. Adzhemyan, S. M. Kolyasov, O. I. Sergienko and S. M. Petrov, Combustion of explosive compounds with nitrogen-nitrogen bonds, Combust., Explos. Shock Waves, 1976, 12, 732740 .

29 L. J. Bellamy, The infrared spectra of complex molecules: Volume two advances in infrared group frequencies, Springer, Netherlands, 2012.

30 R. K. Murmann, R. Glaser and C. L. Barnes, Structure of the nitrosoguanidine complexes of nickel(ii) and copper(ii) by X-ray crystallography and computational analysis, J. Coord. Chem., 2005, 58, 279-294.

31 L. Yang, D. R. Powell and R. P. Houser, Structural variation in copper(i) complexes with pyridylmethylamide ligands: Structural analysis with a new four-coordinate geometry index, [small tau]4, Dalton Trans., 2007, 955-964, DOI: 10.1039/B617136B.

32 F. H. Allen, O. Kennard, D. G. Watson, L. Brammer, A. G. Orpen and R. Taylor, Tables of bond lengths determined by x-ray and neutron diffraction. Part 1 . Bond lengths in organic compounds, J. Chem. Soc., Perkin Trans. 2, 1987, S1-S19, DOI: 10.1039/P298700000S1.

33 K. I. Kulish, A. S. Novikov, P. M. Tolstoy, D. S. Bolotin, N. A. Bokach, A. A. Zolotarev and V. Y. Kukushkin, Solid state and dynamic solution structures of o-carbamidine amidoximes gives further insight into the mechanism of zinc(ii)-mediated generation of 1,2,4-oxadiazoles, J. Mol. Struct., 2016, 1111, 142-150.

34 A. Bondi, Van der waals volumes and radii of metals in covalent compounds, J. Phys. Chem., 1966, 70, 3006-3007. 
35 S. Alvarez, A cartography of the van der Waals territories, Dalton Trans., 2013, 42, 8617-8636.

36 V. W. Yam, V. K. Au and S. Y. Leung, Light-emitting selfassembled materials based on $\mathrm{d}(8)$ and $\mathrm{d}(10)$ transition metal complexes, Chem. Rev., 2015, 115, 7589-7728.

37 R. F. W. Bader, Atoms in molecules: A quantum theory, Oxford University Press, 1990.

38 (a) A. S. Mikherdov, M. A. Kinzhalov, A. S. Novikov, V. P. Boyarskiy, I. A. Boyarskaya, D. V. Dar'in, G. L. Starova and V. Y. Kukushkin, Difference in energy between two distinct types of chalcogen bonds drives regioisomerization of binuclear (diaminocarbene)pdii complexes, J. Am. Chem. Soc., 2016, 138, 14129-14137; (b) K. Kolari, J. Sahamies, E. Kalenius, A. S. Novikov, V. Y. Kukushkin and M. Haukka, Metallophilic interactions in polymeric group 11 thiols, Solid State Sci., 2016, 60, 92-98; (c) T. V. Serebryanskaya, A. S. Novikov, P. V. Gushchin, M. Haukka, R. E. Asfin, P. M. Tolstoy and V. Y. Kukushkin, Identification and h(d)bond energies of $\mathrm{c}-\mathrm{h}(\mathrm{d})[$ three dots, centered]cl interactions in chloride-haloalkane clusters: A combined x-ray crystallographic, spectroscopic, and theoretical study, Phys. Chem. Chem. Phys., 2016, 18, 14104-14112; (d) D. M. Ivanov, A. S. Novikov, I. V. Ananyev, Y. V. Kirina and V. Y. Kukushkin, Halogen bonding between metal centers and halocarbons, Chem. Commun., 2016, 52, 5565-5568.

39 E. R. Johnson, S. Keinan, P. Mori-Sanchez, J. ContrerasGarcia, A. J. Cohen and W. Yang, Revealing noncovalent interactions, J. Am. Chem. Soc., 2010, 132, 6498-6506.

40 E. Espinosa, E. Molins and C. Lecomte, Hydrogen bond strengths revealed by topological analyses of experimentally observed electron densities, Chem. Phys. Lett., 1998, 285, 170-173.

41 M. Vener, A. Egorova, A. Churakov and V. Tsirelson, Intermolecular hydrogen bond energies in crystals evaluated using electron density properties: Dft computations with periodic boundary conditions, J. Comput. Chem., 2012, 33, 2303-2309.

42 S. S. Batsanov, Van der waals radii of elements, Inorg. Mater., 2001, 37, 871-885.

43 E. Espinosa, I. Alkorta, J. Elguero and E. Molins, From weak to strong interactions: A comprehensive analysis of the topological and energetic properties of the electron density distribution involving $\mathrm{x}$-h...F-y systems, J. Chem. Phys., 2002, 117, 5529-5542.

44 (a) M. Weber, J. E. M. N. Klein, B. Miehlich, W. Frey and R. Peters, Monomeric ferrocene bis-imidazoline bis-palladacycles: Variation of pd-pd distances by an interplay of metallophilic, dispersive, and coulombic interactions, Organometallics, 2013, 32, 5810-5817; (b) D. L. J. Broere, S. Demeshko, B. de Bruin, E. A. Pidko, J. N. H. Reek, M. A. Siegler, M. Lutz and J. I. van der Vlugt, Dinuclear palladium complexes with two ligand-centered radicals and a single bridging ligand: Subtle tuning of magnetic properties, Chem. - Eur. J., 2015, 21, 5879-5886; (c) A. Gouranourimi, M. Ghassemzadeh, S. Bahemmat, B. Neumüller and R. Tonner, New palladium(ii) complexes containing 3-mercapto-1,2,4-triazole ligands: Synthesis, characterization, crystal structure, and density functional theory calculations, Monatsh. Chem., 2015, 146, 57-67.

45 (a) M. R. R. Prabhath, J. Romanova, R. J. Curry, S. R. P. Silva and P. D. Jarowski, The role of substituent effects in tuning metallophilic interactions and emission energy of bis-4-(2-pyridyl)-1,2,3-triazolatoplatinum(ii) complexes, Angew. Chem., Int. Ed., 2015, 54, 7949-7953; (b) A. Alessandro, G. Damiano, M. Matteo and D. C. Luisa, Recent advances in phosphorescent pt(ii) complexes featuring metallophilic interactions: Properties and applications, Chem. Lett., 2015, 44, 1152-1169; (c) V. V. Sivchik, E. V. Grachova, A. S. Melnikov, S. N. Smirnov, A. Y. Ivanov, P. Hirva, S. P. Tunik and I. O. Koshevoy, Solid-state and solution metallophilic aggregation of a cationic [pt(ncn)l]+ cyclometalated complex, Inorg. Chem., 2016, 55, 3351-3363; (d) B.-H. Xia, C.-M. Che, D. L. Phillips, K.-H. Leung and K.-K. Cheung, Metal-metal interactions in dinuclear d8 metal cyanide complexes supported by phosphine ligands. Spectroscopic properties and ab initio calculations of $[\mathrm{m} 2(\mu$-diphosphine $) 2(\mathrm{cn}) 4]$ and trans-[m(phosphine $) 2$ (cn)2] (m=pt, ni), Inorg. Chem., 2002, 41, 3866-3875; (e) B.-H. Xia, C.-M. Che and Z.-Y. Zhou, The quest for pdiipdii interactions: Structural and spectroscopic studies and ab initio calculations on dinuclear $[\mathrm{pd} 2(\mathrm{cn}) 4$ ( $\mu$-diphosphane)2] complexes, Chem. - Eur. J., 2003, 9, 3055-3064; (f) H.-K. Yip, T.-F. Lai and C.-M. Che, Metalmetal interaction in a binuclear palladium(ii) system. The $(\mathrm{d}[$ sigma $] *[$ rightward arrow $] \mathrm{p}[$ sigma $])$ transition and the x-ray crystal structure of $[\mathrm{pd} 2(\mathrm{dppm}) 2(\mathrm{cn}) 4][\mathrm{dppm}=$ bis (diphenylphosphino)methane], J. Chem. Soc., Dalton Trans., 1991, 1639-1641, DOI: 10.1039/DT9910001639; (g) I. M. Sluch, A. J. Miranda, O. Elbjeirami, M. A. Omary and L. M. Slaughter, Interplay of metallophilic interactions, $\pi-\pi$ stacking, and ligand substituent effects in the structures and luminescence properties of neutral ptii and pdii aryl isocyanide complexes, Inorg. Chem., 2012, 51, 1072810746.

46 W. Lijinsky, Chemistry and biology of n-nitroso compounds, Cambridge University Press, 1992.

47 (a) V. Y. Kukushkin, V. K. Bel'skii, E. A. Aleksandrova, V. E. Konovalov and G. A. Kirakosyan, Platinum(iv)mediated redox coupling of 2-propanone oximes in cis-[pt $(\mathrm{me} 2 \mathrm{c}=\mathrm{noh}) 2 \mathrm{cl} 4]$ Crystal structure of $[\mathrm{pt}(\mathrm{n}(=\mathrm{o})$ cme2oncme2)cl2], Inorg. Chem., 1992, 31, 3836-3840; (b) V. Y. Kukushkin, D. Tudela, Y. A. Izotova, V. K. Belsky and A. I. Stash, Reactivity of trans-[ptx2(ketoxime)2] complexes toward m-chloroperoxybenzoic acid: An efficient route to coordinated nitrosoalkanes and solvent dependence of the reaction, Inorg. Chem., 1996, 35, 4926-4931.

48 K. V. Luzyanin, P. V. Gushchin, A. J. L. Pombeiro, M. Haukka, V. I. Ovcharenko and V. Y. Kukushkin, Oxidation of pt-bound bis-hydroxylamine as a novel route to unexplored dinitrosoalkane ligated species, Inorg. Chem., 2008, 47, 6919-6930. 
49 L. G. L. Ward and J. R. Pipal, in Inorganic Syntheses, John Wiley \& Sons, Inc., 2007, pp. 154-164, DOI: 10.1002/ 9780470132449.ch30.

50 C. J. P. Barros, Synthesis of amidoximes using an efficient and rapid ultrasound method, J. Chil. Chem. Soc., 2011, 56, 721-722.

51 (a) L. Palatinus and G. Chapuis, Superflip - a computer program for the solution of crystal structures by charge flipping in arbitrary dimensions, J. Appl. Crystallogr., 2007, 40, 786-790; (b) L. Palatinus and A. van der Lee, Symmetry determination following structure solution in p1, J. Appl. Crystallogr., 2008, 41, 975-984; (c) L. Palatinus, S. J. Prathapa and S. van Smaalen, Edma: A computer program for topological analysis of discrete electron densities, J. Appl. Crystallogr., 2012, 45, 575-580.

52 G. Sheldrick, A short history of shelx, Acta Crystallogr., Sect. A: Fundam. Crystallogr., 2008, 64, 112-122.

53 O. V. Dolomanov, L. J. Bourhis, R. J. Gildea, J. A. K. Howard and H. Puschmann, Olex2: A complete structure solution, refinement and analysis program, J. Appl. Crystallogr., 2009, 42, 339-341.

54 Y. Zhao and D. G. Truhlar, The m06 suite of density functionals for main group thermochemistry, thermochemical kinetics, noncovalent interactions, excited states, and transition elements: Two new functionals and systematic testing of four m06-class functionals and 12 other functionals, Theor. Chem. Acc., 2008, 120, 215-241.

55 M. J. Frisch, G. W. Trucks, H. B. Schlegel, G. E. Scuseria, M. A. Robb, J. R. Cheeseman, G. Scalmani, V. Barone, B. Mennucci, G. A. Petersson, H. Nakatsuji, M. Caricato, X. Li, H. P. Hratchian, A. F. Izmaylov, J. Bloino, G. Zheng, J. L. Sonnenberg, M. Hada, M. Ehara, K. Toyota, R. Fukuda, J. Hasegawa, M. Ishida, T. Nakajima, Y. Honda, O. Kitao, H. Nakai, T. Vreven, J. A. Montgomery, J. E. Peralta, F. Ogliaro, M. Bearpark, J. J. Heyd, E. Brothers, K. N. Kudin, V. N. Staroverov, T. Keith, R. Kobayashi, J. Normand, K. Raghavachari, A. Rendell, J. C. Burant, S. S. Iyengar, J. Tomasi, M. Cossi, N. Rega, J. M. Millam,
M. Klene, J. E. Knox, J. B. Cross, V. Bakken, C. Adamo, J. Jaramillo, R. Gomperts, R. E. Stratmann, O. Yazyev, A. J. Austin, R. Cammi, C. Pomelli, J. W. Ochterski, R. L. Martin, K. Morokuma, V. G. Zakrzewski, G. A. Voth, P. Salvador, J. J. Dannenberg, S. Dapprich, A. D. Daniels, O. Farkas, J. B. Foresman, J. V. Ortiz, J. Cioslowski and D. J. Fox, Gaussian 09, Revision C.01, Gaussian, Inc., Wallingford, CT, 2010.

56 M. Reiher, Relativistic douglas-kroll-hess theory, Wiley Interdiscip. Rev.: Comput. Mol. Sci., 2012, 2, 139-149.

57 (a) F. E. Jorge, A. Canal Neto, G. G. Camilett and S. F. Machado, Contracted gaussian basis sets for douglaskroll-hess calculations: Estimating scalar relativistic effects of some atomic and molecular properties, J. Chem. Phys., 2009, 130, 064108; (b) A. Canal Neto and F. E. Jorge, Allelectron double zeta basis sets for the most fifth-row atoms: Application in $\mathrm{dft}$ spectroscopic constant calculations, Chem. Phys. Lett., 2013, 582, 158-162; (c) R. C. de Berrêdo and F. E. Jorge, All-electron double zeta basis sets for platinum: Estimating scalar relativistic effects on platinum(ii) anticancer drugs, J. Mol. Struct. (THEOCHEM), 2010, 961, 107-112; (d) C. L. Barros, P. J. P. de Oliveira, F. E. Jorge, A. Canal Neto and M. Campos, Gaussian basis set of double zeta quality for atoms rb through xe: Application in non-relativistic and relativistic calculations of atomic and molecular properties, Mol. Phys., 2010, 108, 1965-1972.

58 D. Figgen, G. Rauhut, M. Dolg and H. Stoll, Energy-consistent pseudopotentials for group 11 and 12 atoms: Adjustment to multi-configuration dirac-hartree-fock data, Chem. Phys., 2005, 311, 227-244.

59 T. Lu and F. Chen, Multiwfn: A multifunctional wavefunction analyzer, J. Comput. Chem., 2012, 33, 580-592.

60 A. V. Marenich, C. J. Cramer and D. G. Truhlar, Universal solvation model based on solute electron density and on a continuum model of the solvent defined by the bulk dielectric constant and atomic surface tensions, J. Phys. Chem. B, 2009, 113, 6378-6396. 